\title{
Early Jurassic (Sinemurian) gastropods from the Lusitanian Basin (west of Portugal)
}

\author{
Íñigo VITÓN ${ }^{1 *}$, María José COMAS-RENGIFO \& Ricardo PAREDES ${ }^{1,2}$
}

${ }^{1}$ Departamento de Geodinámica, Estratigrafía y Paleontología, Facultad de Ciencias Geológicas, Universidad Complutense de Madrid, Avenida José Antonio Novais, 12, 28040, Madrid, Spain. iviton@ucm.es; mjcomas@ucm.es

${ }^{2}$ Museu da Ciência da Universidade de Coimbra, Largo Marquês de Pombal, 3000-272, Coimbra \& MARE - Marine and Environment Research Centre, Universidade de Coimbra, Portugal. ricardo.paredes@uc.pt

*Corresponding author

Vitón, Í., Comas-Rengifo, M.J. \& Paredes, R. 2020. Early Jurassic (Sinemurian) gastropods from the Lusitanian Basin (west of Portugal). [Gasterópodos del Jurásico Inferior (Sinemuriense) de la Cuenca Lusitánica (oeste de Portugal)]. Spanish Journal of Palaeontology, 35 (2), 147-166.

Manuscript received 17 December 2019

Manuscript accepted 7 March 2020 https://doi.org/10.7203/sjp.35.2.18478

(c) Sociedad Española de Paleontología ISSN 2255-0550

\begin{abstract}
The Sinemurian gastropod specimens herein studied come from two sources: from museum collections and from samplings in field. The study of the Sinemurian gastropod specimens housed in the collections of the Museu Geológico (Laboratório Nacional de Energia e Geologia), Museu Nacional de História Natural e da Ciência (University of Lisbon), Museu da Ciência (University of Coimbra) and of the Museu de História Natural e da Ciência (University of Porto), has allowed the systematic and taxonomical update of this material. These specimens come mostly from Sinemurian outcrops in S. Pedro de Moel area and Coimbra region, and were collected by Paul Choffat and collaborators in the geological field works in relation to the cartography of the Portuguese Geological Map in 1887 and 1903. The review of these collections permitted to recognise original material that was used to describe several characteristic species of the Lusitanian Basin, namely Scurriopsis (Scurriopsis) schmidti, Cryptaenia sp., Nerinella ficalhoi, and Boehmiola exilis.

The study of the specimens sampled in field has allowed confirming the origin and stratigraphic position of those specimens collected by Choffat. This sampling was carried out in materials of Coimbra and Água de Madeiros formations
\end{abstract}

\section{RESUMEN}

Los ejemplares de gasterópodos del Sinemuriense aquí estudiados proceden, por una parte de colecciones de museo, y por otra del muestreo en campo. El estudio de los ejemplares albergados en las colecciones del Museu Geológico (Laboratório Nacional de Energia e Geologia), Museu Nacional de História Natural e da Ciência (Universidad de Lisboa), Museu da Ciência (Universidad de Coimbra) y del Museu de História Natural e da Ciência (Universdad de Oporto), ha permitido la actualización sistemática y taxonómica de este material. Estos ejemplares proceden principalmente de los afloramientos del Sinemuriense del área de S. Pedro de Moel y de la región de Coimbra, y fueron recolectados por Paul Choffat y sus colaboradores en 1887 y 1903 como parte de los trabajos de campo para la cartografía del Mapa Geológico Portugués. En la revisión de estas colecciones, se ha encontrado el material original que fue usado para la descripción de varias especies características de la Cuenca Lusitánica, Scurriopsis (Scurriopsis) schmidti, Cryptaenia sp., Nerinella ficalhoi y Boehmiola exilis.

El estudio de los ejemplares procedentes del muestreo en campo, ha permitido confirmar el origen y la posición estratigráfica de estos ejemplares recolectados por Choffat. 
(Obtusum and Oxynotum chronozones) cropping out in $\mathrm{S}$. Pedro de Moel, Praia Polvoeira, and Praia Pedra do Ouro.

A total of 386 specimens have been studied, 266 have been assigned to 14 taxa of 14 families, 13 genera and 8 species. Most of these taxa belong to the subclass Caenogastropoda $(61.31 \%$ of the specimens), to the order Allogastropoda (30.66\%), and the superfamilies Campaniloidea (28.83\%) and Nerinoidea $(20.8 \%)$. The most common species are endemic of the Lusitanian Basin, namely Pseudomelania costae Pictet \& Campiche, 1862 and Oonia casta Böhm, 1901. Other species are known in Germany, Luxembourg and Austria basins.

Keywords: Systematics, S. Pedro de Moel, Coimbra, Obtusum, Oxynotum.

\section{INTRODUCTION}

Portuguese Sinemurian gastropods, and Lower Jurassic ones in general, were studied mainly in the early $20^{\text {th }}$ century as part of regional geological publications (Sharpe, 1850a; Choffat, 1903; Hallam, 1971) or fossil atlases (Böhm, 1901; Mouterde \& Rocha, 1981). Hallam (1971, p. 255) wrote: "the few [gastropod] species that occur in Portugal are widely distributed forms that call for no special comment, but Nerinella". Few recent studies of the Lusitanian Basin gastropods have been conducted, and none based upon a detailed stratigraphic analysis, although new species are described in Sharpe (1850a), Böhm (1901) and Choffat (1903), and some of them, such as Boehmiola exilis, have been used as guide fossils (Choffat, 1903).

In the last few years, gastropod faunas from other Lower Jurassic European basins have been published, mainly in Germany (Gründel, 2003, 2007a, 2007b, 2010; Nützel \& Gründel, 2015; Schubert et al., 2008), AustriaHungary (Szabó, 2008a, 2016), England (Gründel et al., 2011; Todd \& Munt, 2010) and Italy (Conti et al., 2004; Fischer et al., 2002; Gatto \& Monari, 2010; Szabo et al., 2019). Researches about faunas from France (Gatto et al., 2015), Luxembourg (Monari et al., 2011) and Turkey (Okan \& Hosgör, 2007), and other non-European countries, such as Argentina (Damborenea \& Ferrari, 2008; Ferrari, 2009, 2013, 2014; Ferrari et al., 2014) have also been published. This work aims to provide taxonomical update of the Sinemurian gastropods of the Lusitanian Basin.
Este muestreo fue realizado en los materiales de las formaciones Coimbra y Água de Madeiros (cronozonas Obtusum y Oxynotum), que afloran en S. Pedro de Moel, Praia Polvoeira y Praia Pedra do Ouro.

Se han estudiado un total de 386 ejemplares, de los cuales 266 han sido asignados a 14 taxones de 14 familias, 13 géneros y 8 especies. La mayoría de estos taxones pertenecen a la subclase Caenogastropoda (61,31\% de los ejemplares), al orden Allogastropoda (30,66\%), y a las superfamilias Campaniloidea $(28,83 \%)$ y Nerinoidea $(20,8 \%)$. Los taxones más frecuentes son endémicos de la Cuenca Lusitánica, como Pseudomelania costae Pictet y Campiche, 1862 y Oonia casta Böhm, 1901. Otros taxones determinados se han reconocido también en cuencas de Alemania, Luxemburgo y Austria.

Palabras clave: Sistemática, S. Pedro de Moel, Coimbra, Obtusum, Oxynotum.

\section{GEOLOGICAL AND GEOGRAPHICAL CONTEXTS}

The Sinemurian in the Lusitanian Basin (LB, W Portugal) crops out in three main geographical areas: S. Pedro de Moel, the outskirts of Coimbra and Peniche (Fig. 1). Due to anthropic changes in the landscape, the outcrops on the outskirts of Coimbra are no longer accessible as they were 100 years ago and the specimens in museum collections are therefore the most available source of palaeontological and geological information for this area.

Most of the gastropods studied were collected from the central-coastal region of the basin (Fig. 1). S. Pedro de Moel (Leiria district, Extremadura province) is the nearest reference location, in which two areas can be distinguished and summarised as North and South. The most complete and representative Sinemurian successions of the LB (Comas-Rengifo et al., 2013) crop out in these areas. In the North, Penedo do Cabo (SPM) section, between Praia Velha (PV) and Praia da Concha, $600 \mathrm{~m}$ north of Penedo da Saudade lighthouse, shows the lower part of the Coimbra Formation (Fm.), Obtusum chronozone (Fig. 2), which is represented as unit D in Azêredo et al. (2010; fig. 3). In the south, $3.5 \mathrm{~km}$ from S. Pedro de Moel, lies Praia Pedra do Ouro (OU) and Praia da Polvoeira (PO) sections; they both show the upper part of Obtusum chronozone and lower part of Oxynotum chronozone (Fig. 2).

A continuous carbonate succession crops out from PV to $\mathrm{PO}$, which represents three second-order transgressiveregressive subcycles (Azerêdo et al., 2010, 2014; ComasRengifo et al., 2013; Duarte et al., 2008; Paredes et al., 2016). The materials containing gastropods are in a transgressive subcycle with a maximum flood event in the Água de Madeiros Fm. 

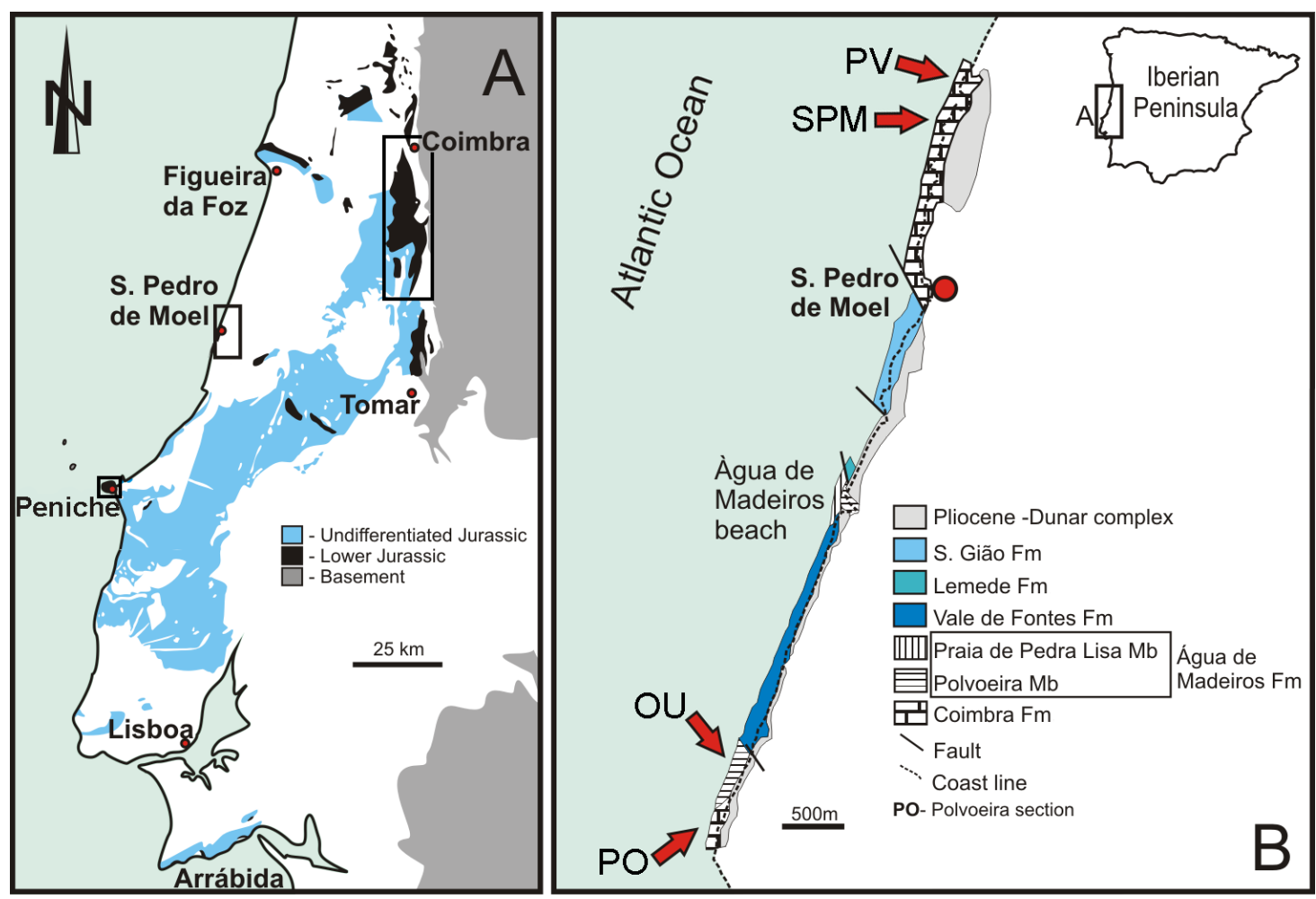

Figure 1. a) Geographical situation of the Jurassic outcrops studied in S. Pedro de Moel, Coimbra and Peniche. b) Detail of the S. Pedro de Moel area within a geological context. Modified from Duarte et al. (2008).

Azêredo et al. (2010, 2014) subdivided the Penedo do Cabo sedimentary succession into several lithological units. Five big limestone samples named SPM and PV were studied (Figs 2-3), coming from the lower part of unit D (Azêredo et al., 2010, 2014), where bivalves are rare and small, and gastropods are common. Unit D is characterised by $25 \mathrm{~m}$ of limestones and marl-limestones alternating in layers of variable thickness, with marl interbeds that become increasingly thicker towards the top. The materials are highly bioturbated and the most frequent macrofossils are gastropods, bivalves and echinoderms. The gastropods and bivalves do not show a prevalent orientation, nor a homogeneous distribution, and show a medium level of fragmentation, with some specimens almost complete and others very fragmented. Fossils are concentrated in the lower part of almost every layer. The material studied comes from between layers 311 and 323 of Azêredo et al. (2010, 2014), which Dommergues et al. (2010) dated as upper Sinemurian, Obtusum chronozone. Layer 322 is the richest in fossils.

Two taphofacies (sensu Fernández-López, 2000) can be described in unit D (Fig. 4). Taphofacies type 1 is characterised by mudstone with evidence of rapid burial and a high sedimentation rate, where the gastropod specimens are found partially infilled with sediment and recrystallized. Taphofacies type 2 is characterised by a wackestone-packstone, associated with slow burial and a low sedimentation rate. Gastropods are usually found as inner moulds, although complete shells are also present in some layers showing few traces of re-sedimentation, with the presence of articulated skeletons of echinoderms.

The sediments of the upper part of the Coimbra Fm. (around $25 \mathrm{~m}$ ) and the lower part of the Água de Madeiros Fm. (Polvoeira Mb.) crop out to the south of S. Pedro de Moel, between PO and OU (Figs 1, 5). They were studied by Duarte et al. (2010), Paredes (2012), and Paredes et al. $(2013,2016)$ in relation to benthic associations. The gastropods studied herein were collected bed by bed. The lower part of the section is represented by limestones, sometimes bioclastic, marl-limestones and marlstones with some layers of black shales (high level of organic matter). As from the layer PO122, and all along the Água de Madeiros Fm., an increase in marl and black layers can be observed which, according to Paredes et al. (2016), coincides with the beginning of a transgressive cycle. This also coincides with an increase in the diversity of brachiopods, bivalves and gastropods (Fig. 5).

The Coimbra Fm. outcrops from the northern area of the LB, where some specimens of the Portuguese Geological Services come from, is often represented by dolomitic series; thus the gastropods are badly preserved. At present, these outcrops are not always visible because covered by vegetation and new buildings. 

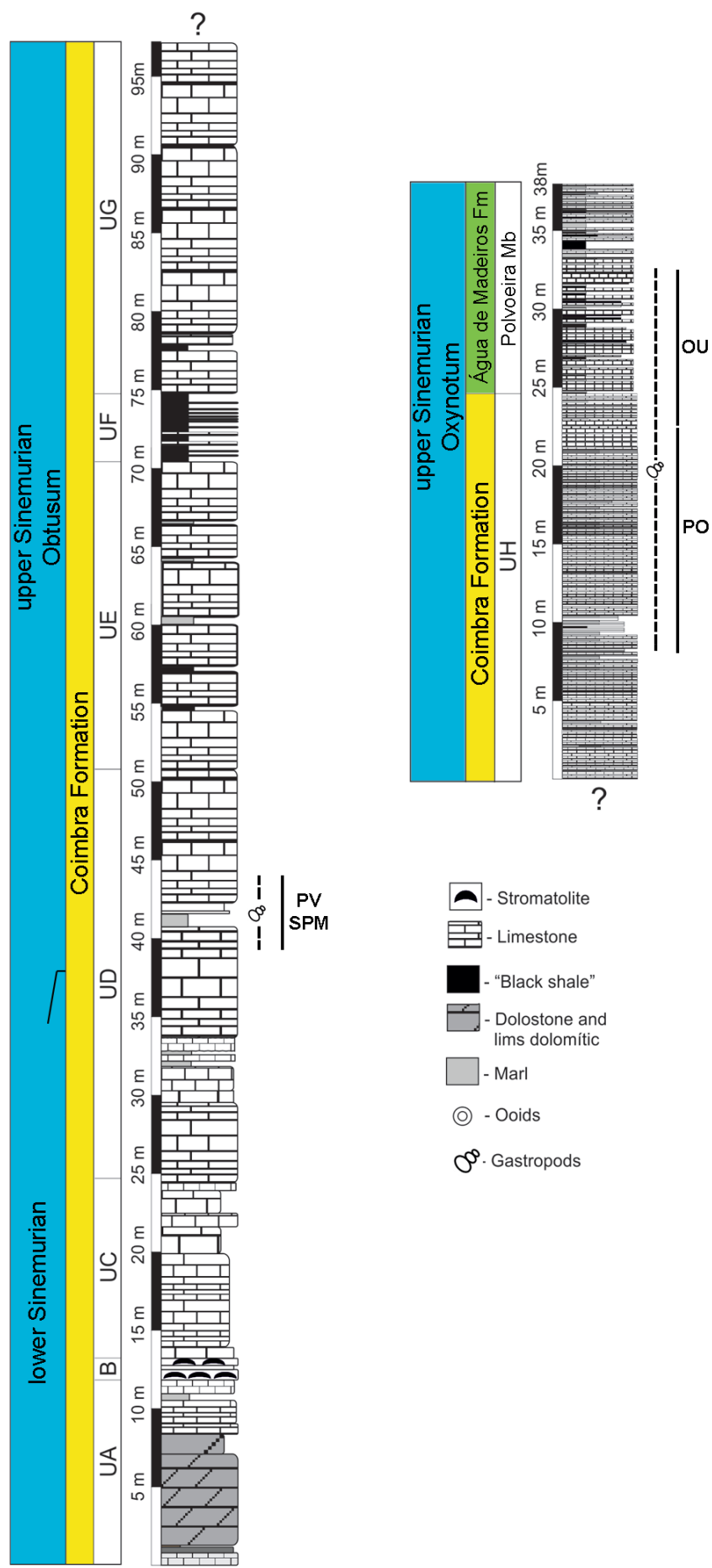

Figure 2. Composite stratigraphic log of the S. Pedro de Moel (SPM) region outcrops of Coimbra Fm. and Polveira Mb. (Água de Madeiros Fm). Lower Jurassic outcrops, between Praia Velha (PV) and Praia da Polvoeira (PO). Modified from Duarte et al. (2012). UA-UH: stratigraphic units defined by Azerêdo et al. (2010).

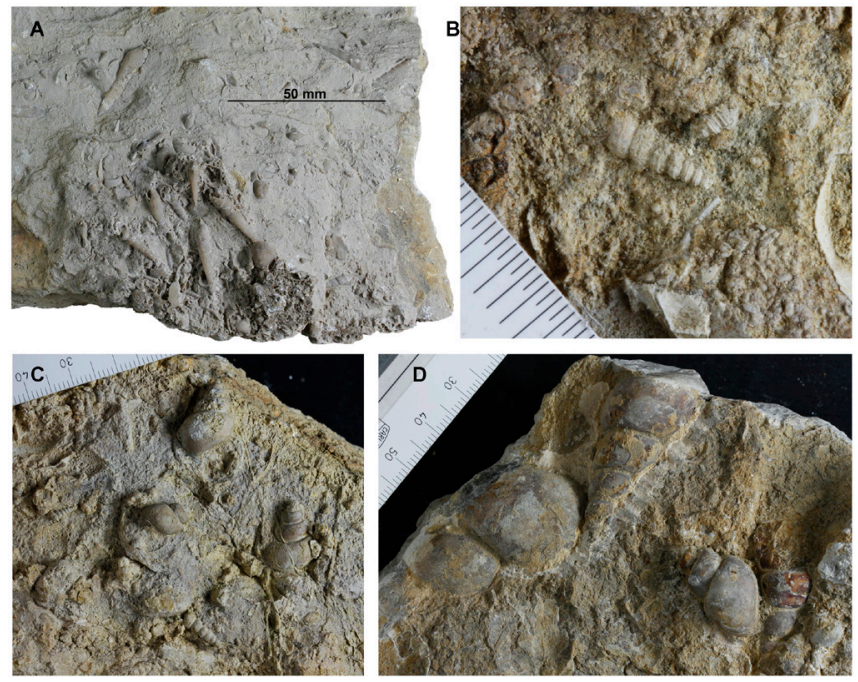

Figure 3. Examples of the diversity of Sinemurian gastropods from the S. Pedro de Moel area. a) SPM, Penedo do Cabo. b-d) PV, Praia Velha: (b) PV322b_1; (c) PV322b_2; (d) PV322mt. Photos: C. Alonso.

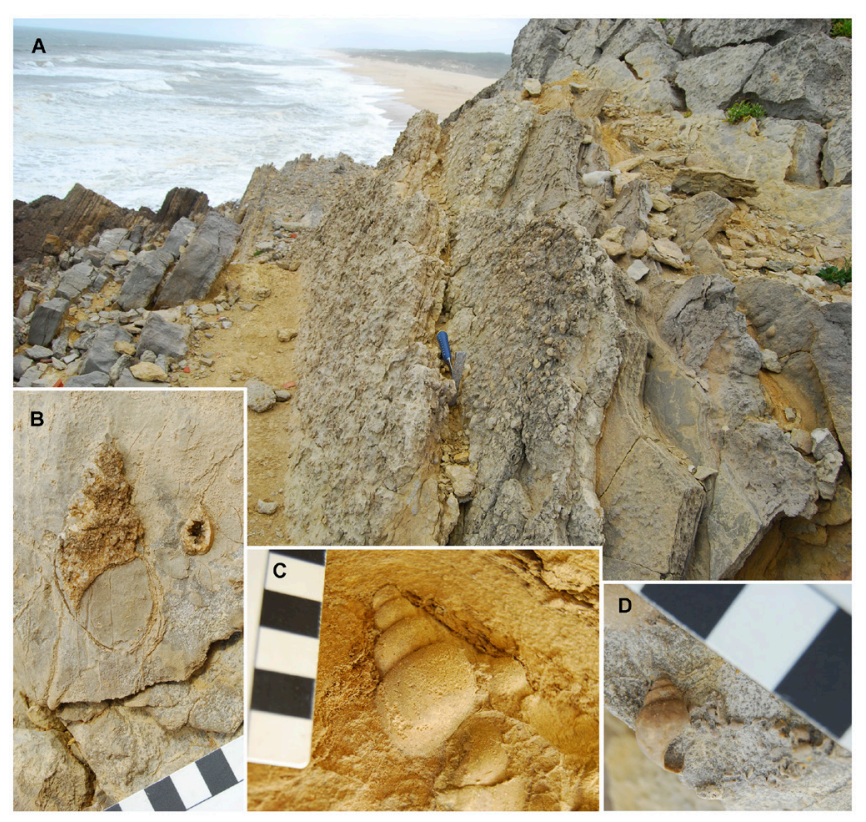

Figure 4. Examples of taphofacies recognised in Praia Velha (PV) outcrop. a) Levels 311 to 378 , the hammer is on bed 322. b) Taphofacies type 1 . c) Taphofacies type 2, inner mould. d) Taphofacies type 2, shell preserved. Scale in (b-d) is in centimetres. Photos: R. Paredes.

\section{MATERIAL AND METHODS}

Five museum collections were accessed for the present paper: the Museu Geológico de Portugal (SGP), the Museu Nacional de História Natural e da Ciência (MUHNAC), the LNEG Archive (Alfragide), the Museu da Ciência Universidade de Coimbra (MCUC.MIN), and the Museu de História Natural e da Ciência - Universidade do Porto (UP. 


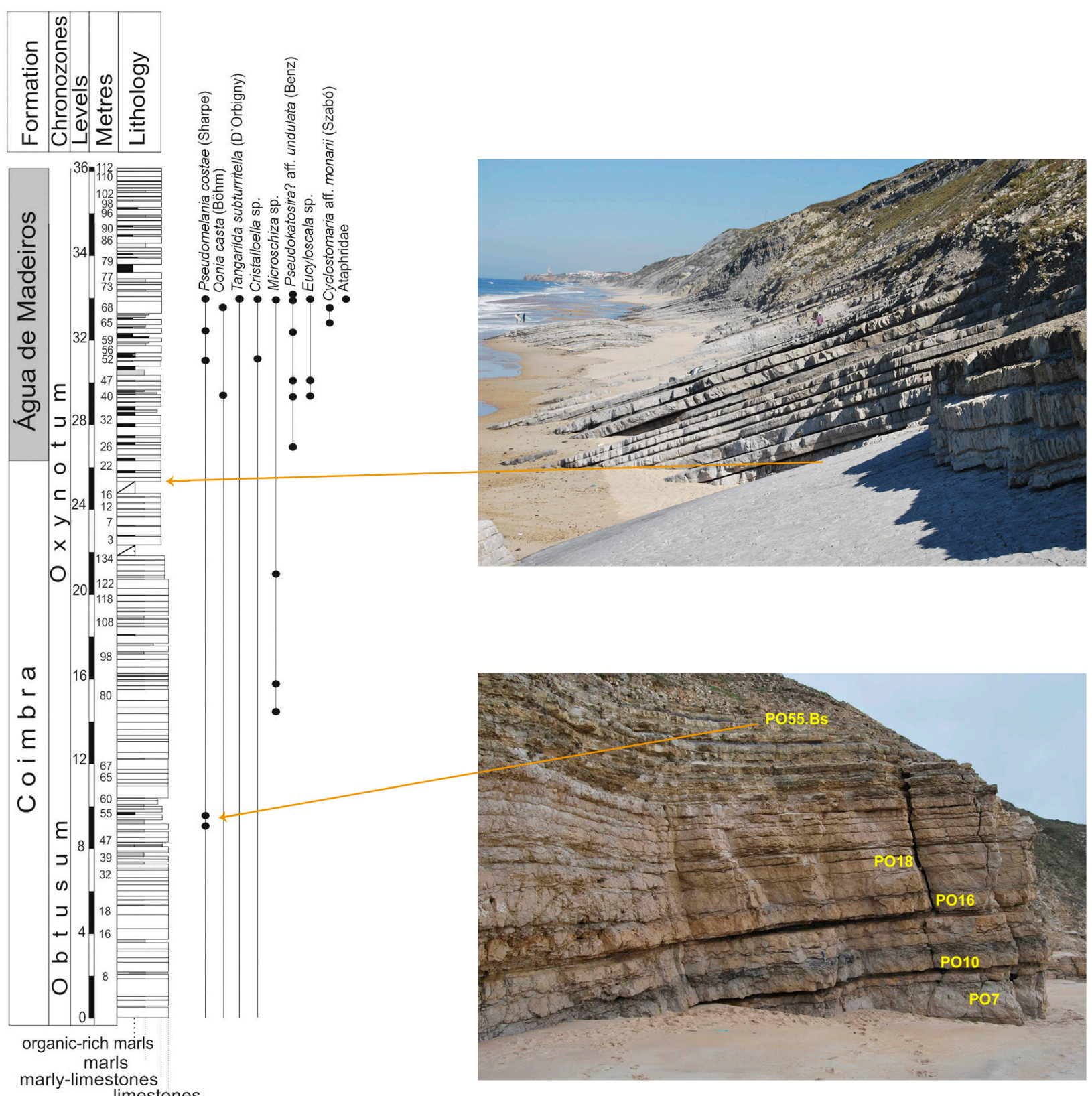

Figure 5. Stratigraphic log of the Praia Polvoeira beach (PO) and Praia Pedra do Ouro beach (OU) sections with the stratigraphic gastropod distribution. Modified from Duarte et al. (2012). Photos: R. Paredes.

MHNFCP). In addition, a detailed bed by bed sampling in S. Pedro de Moel was performed in the Penedo do Cabo outcrop (SPM and PV), at Praia Pedra do Ouro (OU) and at Praia Polvoeira (PO). The museum collection specimens come from the S. Pedro de Moel region and from the outskirts of Coimbra; furthermore, one specimen come from Peniche (Table 1; Supplementary Information).

In the SGP collection, the original catalogue numbers of the specimens have been kept. In addition, new official numbers (from SGP31700 to SGP31889) have been introduced for the other specimens collected in $19^{\text {th }}-20^{\text {th }}$ century lacking a catalogue number. At the
MUHNAC, the numbers are provisional, because the specimens studied have not yet been catalogued. The alphanumeric abbreviation refers to the drawer row and the following number refers to the drawer number in the storage organization of the collection. Choffat and his collectors also collected the specimens with the acronym MCUC.MIN and UP.MHNFCP thereafter referred. That material was originally housed in the SGP collection. Afterwards, some duplicates were sent in $20^{\text {th }}$ century to Lisbon, Coimbra (in 1925) and Porto Universities, for Palaeontology teaching purposes where geology and palaeontology were introduced as new disciplines. 
Table 1. Relation of fossil localities and number of identified specimens in the museum collections.

\begin{tabular}{|c|c|c|c|c|c|}
\hline Area & Locality & SGP & MCUC & UP.MHNFCP & MUHNAC \\
\hline \multirow{4}{*}{$\begin{array}{l}\text { S. Pedro } \\
\text { de Moel }\end{array}$} & $\begin{array}{l}\text { Polvoeira } \\
\text { (S Água de } \\
\text { Madeiros) }\end{array}$ & 22 & 5 & & \\
\hline & $\begin{array}{l}\text { Ninho do } \\
\text { Corvo } \\
\text { (N do farol) }\end{array}$ & 8 & 20 & & \\
\hline & $\begin{array}{l}\text { Penedo do } \\
\text { Cabo } \\
\text { (N Pedrianes) }\end{array}$ & 53 & 28 & & \\
\hline & $\begin{array}{l}\text { Praia S. Pedro } \\
\text { de Moel }\end{array}$ & & 6 & & \\
\hline \multirow{9}{*}{ Coimbra } & Undefined & & & 2 & \\
\hline & Coimbra & 1 & & & \\
\hline & Palheira & 2 & & & \\
\hline & Monte de Vera & 8 & & & \\
\hline & $\begin{array}{l}\text { Volta do } \\
\text { Monte }\end{array}$ & 10 & & & \\
\hline & Alcouce & 1 & & & \\
\hline & $\begin{array}{l}\text { Almaroz } \\
\text { (Almalaguês) }\end{array}$ & 11 & & & \\
\hline & $\begin{array}{l}\text { Villa Secca / } \\
\text { Almaroz }\end{array}$ & 9 & & & \\
\hline & $\begin{array}{l}\text { Miranda do } \\
\text { Corvo }\end{array}$ & 8 & & & \\
\hline Peniche & Peniche & 1 & & & \\
\hline Unknown & & 13 & 3 & & 5 \\
\hline Total & & 147 & 62 & 2 & 5 \\
\hline
\end{tabular}

In the present paper we employ the measurements proposed by Gatto \& Monari (2010) (Fig. 6), following the terminology used by Cox (1960). The linear measurements were taken with the use of a calliper (Vogel GermanyElectronic Digital Calliper) when possible, and when not, on digital images using the software Adobe Photoshop to $0.1 \mathrm{~mm}$ accuracy. The angular measurements were taken with Adobe Photoshop CS6 version 13.0.1. In the Systematic chapter, all the measurements are given in millimetres. Numbers in italics mean that measurement is approximate ( $\operatorname{circa}$ ) due to fragmentation or state of preservation. The measurements of taxa are those that better represent the average of all the material studied.

The photos were taken with different cameras (Canon 7D, Nikon D60 and Olympus) and a microscope (Leica MZ16A associated with the software LAS - Leica Application Suite - v3.8). The best-preserved specimens were coated with magnesium oxide in order to enhance sculpture for photography.

The non-museum collection specimens referred hereafter are housed at the Departamento de Geodinámica, Estratigrafía y Paleontología, Facultad de Ciencias Geológicas, Universidad Complutense de Madrid. The identifying numbers make reference to the levels represent in Figure 5.

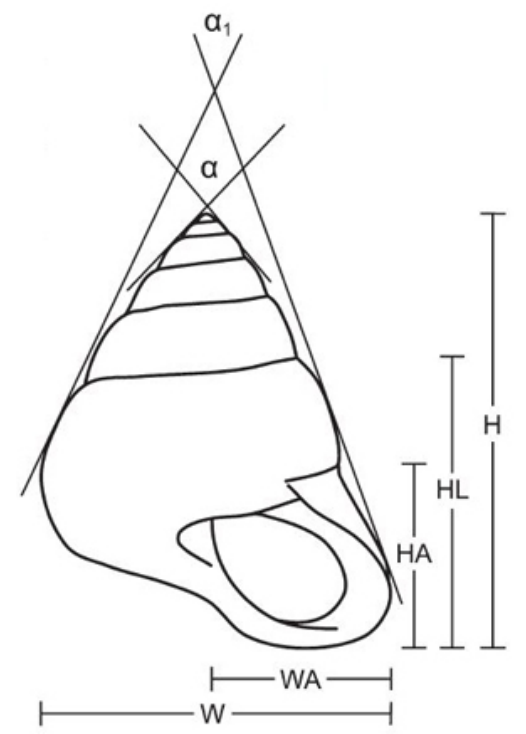

Figure 6. Measured parametres. H: Height of the shell; HL: Height of the last whorl; HA: Height of the aperture; W: Width of the shell; WA: Width of the aperture; $\alpha$ : Apical angle; $\alpha 1$ : Pleural angle. Modified from Gatto \& Monari (2010).

\section{SYSTEMATIC PALAEONTOLOGY}

The systematic is based on Bouchet et al. (2017), who modified significantly the hierarchical order made by previous authors, hence they "purposely abstained to attribute an author and date to names above superfamily". Therefore, we will follow their criteria. For some specific issues, Gründel $(2001,2008,2010)$ and Conti et al. (2004) have been taken into account.

Class GASTROPODA Cuvier, 1795

Subclass PATELLOGASTROPODA

Order PATELLIDA

Superfamily Lottioidea Gray, 1840

Family Acmaeidae Forbes, 1850

Genus Scurriopsis Gemmellaro, 1879

Subgenus Scurriopsis Gemmellaro, 1879 
Scurriopsis (Scurriopsis) schmidti (Dunker, 1844)

(Fig. 7a)

1846 Patella schmidtii; Dunker, p. 187.

1855 Patella schmidtii Dunker; Terquem, p. 281, Pl. 18, figs. 4 (4, 4a, 4b).

v 1901 Patella delgadoi sp. nov.; Böhm, p. 213, Pl. 8, figs. 1-2, Text-fig. 1.

1988 Scurriopsis schmidtii; Meier \& Meiers, p. 25, Pl. 2, figs. 4a-b.
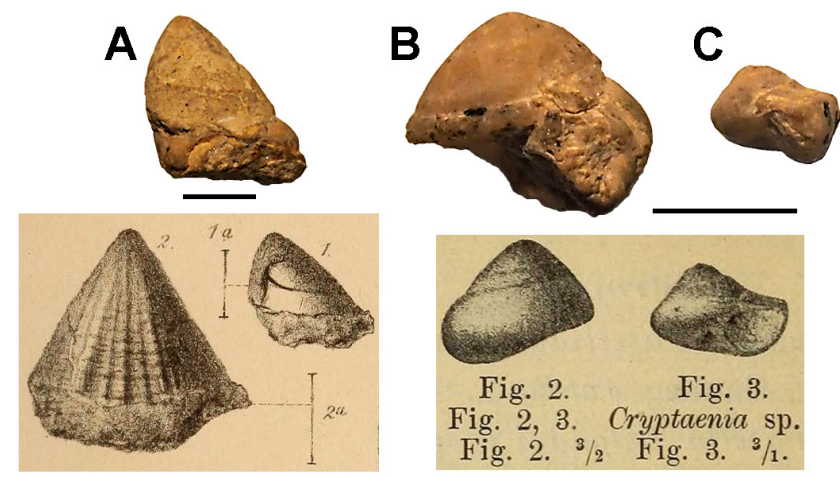

Figure 7. In the lower part of the figure are the original drawings by Böhm (1901) of Scurriopsis (Scurriopsis) schmidti (=Patella delgadoi in Böhm, 1901) (left) and Cryptaenia sp. (right). a) Scurriopsis (Scurriopsis) schmidti, SGP1283. b-c) Cryptaenia sp. (b) SGP1284(1); (c) SGP1284(2). Scale bars = $5 \mathrm{~mm}$. Photos: R. Paredes.

2010 Scurriopsis (Scurriopsis) schmidti (Dunker); Gründel, p. 4, Pl. 1, figs. 1-2.

2011 Scurriopsis (Scurriopsis) schmidti; Monari et al., p. 352, Fig. $5 \mathrm{~A}-\mathrm{C}$.

Material. 1 specimen: SGP1283, Sinemurian.

Description. Shell limpet-shaped. The apex is placed anteriorly in relation with the medium axis of the shell length. In lateral view, posterior outline slightly convex and anterior outline straight. Aperture and ornamentation not visible.

Remarks. According to Monari et al. (2011), Patella delgadoi differs from the material of Luxembourg ascribed by them to $S$. (S.) schmidti only in having a higher shell. Since the other differences could be explained merely by intraspecific variation, these authors let open the possibility that $P$. delgadoi is synonymous of Dunker's species.
This species is cited in the Hettangian of Luxembourg, France and Germany.

\section{Subclass VETIGASTROPODA \\ Order PLEUROTOMARIIDA}

Superfamily Eotomarioidea Wenz, 1938

Family Gosseletinidae Wenz, 1938

Genus Cyclostomaria Szabó, 1980

Cyclostomaria aff. monarii Szabó, 2008b

(Fig. 12.1)

aff. 2008b Cyclostomaria monarii sp. nov.; Szabó, p.174, figs. 4.1-4.7.

Material. 4 specimens: SGP31714, SGP31821?, OU.65, OU.68.11, upper Sinemurian, Oxynotum chronozone.

Description. All of the specimens are cross-sections of a low-spired shell. Last whorl well convex, rounded. Specimen OU68.11 preserves a fragment of shell displaying a moderately wide selenizone that runs slightly above the periphery, and shell ornamented with spiral threads and collabral riblets. The number of threads and riblets cannot be counted because there are not completed whorls. Collabral riblets, irregularly sized and distributed, dominate in the adapical area of the whorl, whereas spiral ones dominate in the abapical region.

Remarks. The morphological characters of these specimens are similar to those described by Szabó (2008b) for Cyclostomaria monarii from the Pliensbachian, Margaritatus chronozone of the Bakony Mountains (Hungary). Specimens herein described and Cyclostomaria monarii differ in the position of the selenizone, whereas in C. monarii it is in a central position, near the mid-line of the whorl surface between the periphery and the adapical suture, in the specimens herein described, the selenizone runs just above the periphery.

Superfamily Ptychomphaloidea Wenz, 1939

Family Ptychomphalidae Wenz, 1938

Remarks. Some authors, as Gründel (2001), argue that Ptychomphalidae should be in superfamily Eotomarioidea instead of Ptychomphaloidea. Bandel (2009) consider the position in superfamily Ptychomphaloidea because of temporal divergence between the type species of Eotomaria (Ordovician) and Ptychomphalus (Jurassic), although admitting close similarities between both genera. Bouchet et al. (2017) compiled Bandel's position. 
Genus Cryptaenia Deslongchamps, 1864

Cryptaenia sp.

(Figs $7 b-7 c)$

v. 1901 Cryptaenia sp.; Böhm, p. 213, Text-figs. 2-3.

Material. 1 specimen: SGP1284, Sinemurian.

Description. Shell cyrtoconoidal and sublenticular with low spire. Four whorls flat with flush sutures. The last whorls are not complete and the aperture is missing. Ornamentation is not preserved or is lacking. The presence of the selenizone cannot be assessed.

Remarks. According to Böhm (1901) these two specimens could represent two different species. Ferrari (2014) pointed out that Cryptaenia is very similar to Ptychomphalus. Many species traditionally assigned to the former are currently included in the latter. The specimen described and figured by Böhm (1901), here re-illustrated (Figs 10a-10b), has not been reviewed in any recent publication; thus, further material is required in order to perform an in-depth analysis and to clarify its specific taxonomic position.

The genus Cryptaenia has also been cited in the Lower Jurassic (Hettangian-Pliensbachian) of Europe and South America (Ferrari, 2014).

\section{Order SEGUENZIIDA}

\section{Superfamily Seguenzioidea Verrill, 1884}

Family Eucyclidae Koken, 1896

Remarks. The systematics of the family Eucyclidae is controversial. Some authors, such as Okan \& Hosgör (2007), Szabó (2008a), Monari et al. (2011), and Szabó et al. (2019) include it in the superfamily Eucycloidea. Others, such as Gründel (2007a), consider that it belongs to the superfamily Trochoidea. Todd \& Munt (2010), Ferrari et al. (2014), and Ferrari \& Kaim (2019) place it in the superfamily Seguenzioidea.

Following Bouchet \& Rocroi (2005) and Bouchet et al. (2017), the Eucyclidae family is included in the superfamily Seguenzioidea. As Monari et al. (2011) and Szabó et al. (2019) pointed out, this classification is based upon molecular analysis (Kano, 2008), although there are substantial morphological and anatomical differences between eucyclids and seguenzioids that justify as well its assignation to superfamily Eucycloidea.

Subfamily Eucycloscalinae Gründel, 2007a

Genus Eucycloscala Cossmann, 1895
Eucycloscala sp.

(Figs 12.2-12.3)

cf. 2007a Eucycloscala sp. cf. brunhuberi (Schnittmann); Gründel, p. 7, pl. 2, fig. 3.

Material. 15 specimens: SGP $(31700,31708-31713$, 31716?), Sinemurian; OU (40.7, 40.8, 40.42, 47.12, 69.2, 69.7, 69.9), upper Sinemurian, Oxynotum chronozone.

Measurements.

\begin{tabular}{l|l|l|l|l|l}
\hline Label & H & HL & HA & W & WA \\
\hline SGP31713 & 16.5 & 11.4 & 6.3 & 13.1 & 5.5 \\
\hline
\end{tabular}

Description. The specimens partially preserve the shell. The spire is conoidal. The state of preservation does not allow the surface or the outline of the teleoconch to be observed. The peristome is subcircular. A spiral keel, thickened by small nodules, can be observed in the lower part of each whorl at periphery. In the first whorls (the intermediate whorls are not visible in any of the specimens), spiral and collabral ribs intersect, giving to the ornament a mesh-like appearance. On the base both types of ribs are also visible, although the collabrals are thinner.

Remarks. Gründel (2007a) gives a description of Eucycloscala cf. brunhuberi based on juvenile specimens, from Sinemurian, Obtusum chronozone, of SW Germany. The specimens here described could be similar to this species, but it cannot be assured that they are the same because of the state of preservation.

The SGP specimens are labelled as coming from Polvoeira (Table 1). As Pedra do Ouro is very near, perhaps in the original labels Pedra do Ouro and Polvoeira were considered as one single location and these specimens might also come from the OU40-OU69 layers.

\section{Order TROCHIDA}

Superfamily Trochoidea Rafinesque, 1815

Family Ataphridae Cossmann, 1915

Remarks. Kaim et al. (2014) considered Ataphrus Gabb, 1869 as nomen dubium, because as they pointed out, and Bouchet et al. (2017) compiled, the holotype of the type species Ataphrus crassus Gabb, 1869 is poorly preserved and both its type locality and age are uncertain. For this reason, they substituted the family name Ataphridae with Collonidae. However, Monari et al. (2018) maintained that this view is not justified. According to these authors, although the holotype is imperfectly preserved, it shows all the characters indicated in the original diagnosis and the uncertainty about its origin does 
not affect the availability of the taxon. The priority of the family name Ataphridae against Colloniidae is discussed in Conti et al. (2004) and Gründel (2008).

\section{Ataphridae indet.}

(Fig. 12.4)

Material. 1 specimen: OU.69.10, upper Sinemurian, Oxynotum chronozone.

\section{Measurements.}

\begin{tabular}{l|l|l|l|l|l|l|l}
\hline Label & H & HL & HA & W & WA & $\boldsymbol{\alpha}$ & $\boldsymbol{\alpha}_{\mathbf{1}}$ \\
\hline OU.69.10 & 5.6 & 3.7 & - & 5.9 & - & - & 55.7 \\
\hline
\end{tabular}

Description. Recrystallized shell. Shell turbiniform with low spire. Four well convex whorls with well impressed suture. The last whorl is not complete and the aperture is missing. Ornamentation is not preserved or is lacked.

Remarks. Due to the scarcity of the material and the poor state of preservation of OU.69.10, we cannot give a more precise taxonomical assignation.

\section{Subclass CAENOGASTROPODA}

Family Pseudomelaniidae Hoernes, 1884

Genus Pseudomelania Pictet \& Campiche, 1862

Remarks. According to Kaim (2004), this genus is in doubt due to the fact that the original material of the type species, Pseudomelania gresslyi Pictet \& Campiche, 1862 , is an indeterminable inner mould. Species generally included in this genus have shells with a high, slender spire, not umbilicate, oval-shaped aperture and without ornamentation.

\section{Pseudomelania costae (Sharpe, 1850a)}

(Figs 8, 12.5-12.7)

1850a Rostellaria costae sp. nov.; Sharpe, p. 193, Pl. 20, fig.1.

v. 1981 Pseudomelania costae; Mouterde \& Rocha, p. 59, Pl. 2, fig. 4.

Material. 48 specimens: MCUC.MIN (2999-3001, 3032, 3033, 3035, 3066, 3067, 3078-3082), SGP (1016, 1017, 31715, 31727-31731, 31763?, 31774?, 31777, 31778?, 31779-31785, 31787, 31791, 31792, 31841, 31881, 31888), MUHNAC.G2.21.1.1, UP.MHNFCP.154782, UP.MHNFCP.154821, Sinemurian; PO (51, 54.1, 54.2), upper Sinemurian, Obtusum chronozone; OU (52.21, 62.19-5, 69.42-1, 69.56), upper Sinemurian, Oxynotum chronozone.

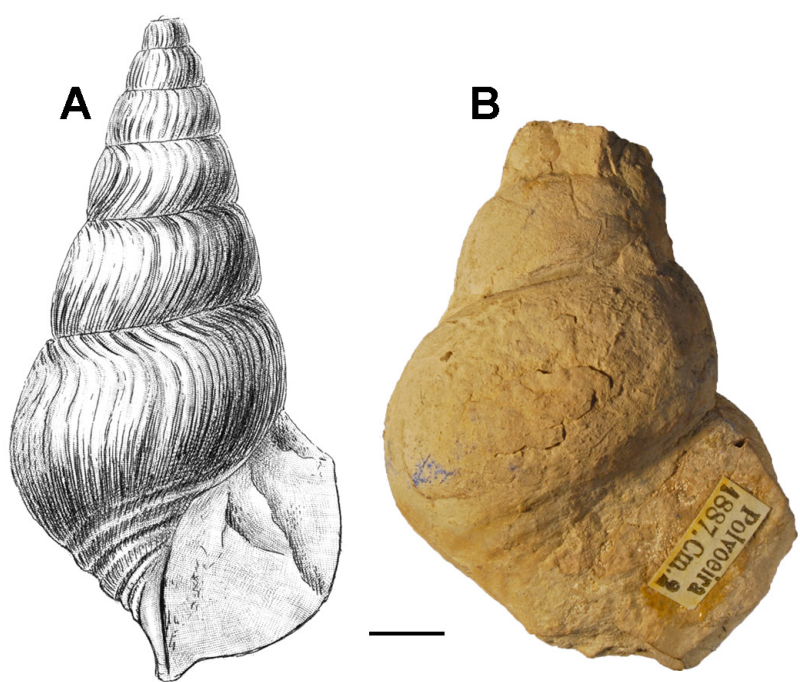

Figure 8. Pseudomelania costae specimens. a) Original drawing by Sharpe (1850a). b) Specimen SGP31715 (Polvoeira). Scale bar $=10 \mathrm{~mm}$. Photo: R. Paredes.

\section{Measurements.}

\begin{tabular}{l|l|l|l|l|l|l|l}
\hline Label & H & HL & HA & W & WA & $\boldsymbol{\alpha}$ & $\boldsymbol{\alpha}_{1}$ \\
\hline MIN.2999 & 77.4 & 40.1 & 18.7 & 33.7 & - & 34.3 & 30.2 \\
\hline PO.54.2 & 90.0 & 56.0 & - & 47.0 & - & - & 40.1 \\
\hline
\end{tabular}

Description. Inner moulds with variable preservation. Shell moderately high-spired, fusiform. The protoconch is not preserved. The teleoconch displays up to nine whorls, last whorl large. Whorl sides variable from convex initially, to almost flat on later whorls. Suture slightly oblique, impressed. Base round and convex. The aperture is not complete, probably elliptical, higher than wide, but a columellar fold (plait) can be frequently observed. Twothree thick marked spiral cords on base. Opisthocline growth lines and spiral cords on the base.

Remarks. According to Sharpe (1850a) the type material cames from "subcretaceous series at San Pedro de Muriel, near Meirinha Grande". Afterwards, Mouterde \& Rocha (1981) described one specimen from "lower Lotharingian" of S. Pedro de Moel. San Pedro de Muriel is currently named S. Pedro de Moel, and the subcretaceous series must refer to the Lower Jurassic (likely Obtusum chronozone, Sinemurian, as it is inferred from the denomination "lower Lotharingian" by Mouterde \& Rocha (1981)) outcrops herein described (Fig. 1).

Superfamily Pseudozyglopleuroidea Knight, 1930

Family Zygopleuridae Wenz, 1938

Subfamily Zygopleurinae Wenz, 1938

Genus Pseudokatosira Nützel \& Gründel, 2007 
Pseudokatosira? aff. undulata Benz, 1832

(Fig. 12.8)

1832 Turritella undulata sp. nov. Benz in Zieten, S. 43 , af. 32 , fig. 2.

1861 Chemnitzia undulata Benz; Stoliczka, p. 163, Pl. 1, fig. 1.

2007 Pseudokatosira undulata (Benz, 1830); Nützel \& Gründel, p. 62, Pl. 1, figs. 1-6.

2008a Pseudokatosira? aff. undulata; Szabó, p. 91, figs. 84A-B, J-K.

2010 Pseudokatosira undulata (Benz); Todd \& Munt, p.162, Pl. 24, fig. 2.

2015 Pseudokatosira undulata (Benz, 1832 in Zieten); Nützel and Gründel, p. 16, Pl. 8, figs. A-E.

Material. 31 specimens: SGP (31701-31707, 31824, $31835,31887)$, Sinemurian; OU $(26.21,26.40,40.1,40.2$, $40.4,40.10,47.1,47.2,47.4,62.1,62.2,62.3,62.4,62.5$, 62.6-1, 62.6-2, 62.19-3, 69.3, 69.4, 69.35, 71), upper Sinemurian, Oxynotum chronozone.

\section{Measurements.}

\begin{tabular}{l|l|l|l|l|l|l|l}
\hline Label & H & HL & HA & W & WA & $\boldsymbol{\alpha}$ & $\boldsymbol{\alpha}_{1}$ \\
\hline OU.40.1 & 18.5 & 5.5 & 2.2 & 5.1 & - & 30.5 & 15.6 \\
\hline OU.62.1 & 16.4 & 5.7 & 3.2 & 5.5 & - & 40.3 & 17.6 \\
\hline
\end{tabular}

Description. Some specimens preserve the shell. The protoconch is not preserved. The teleoconch has ten whorls, with slightly convex flanks and a slightly impressed suture. The base is round. The peristome is continuous and elliptical, with an angular adapical border. Collabral ornamentation is represented in every whorl by opisthocyrt continuous and closely set ribs. The number of ribs cannot be established because the specimens are embedded in the matrix. Specimens OU40.1 and OU40.10 possess up to 11 ribs, which enables an estimation of between 13 and 18 ribs per whorl.

Remarks. Hallam (1971) quoted the presence of the genus Katosira in S. Pedro de Moel, Oxynotum chronozone, although neither description nor figure is available; however, he is likely referring to this species. Szabó (2008a) cited this species in the upper Sinemurian, Oxynotum chronozone of the Austrian Alps.

The specimens SGP31701-31706 preserve the original labels, which indicate that these specimens come from Polvoeira locality. As Pedra do Ouro is very near, perhaps in the original labels Pedra do Ouro and Polvoeira were considered as one single location and the specimens
SGP31701-31706 might also come from the OU26 to OU71 layers. The original location of specimen SGP31835 is Palheira, an inner outcrop nearby Coimbra.

\section{Superfamily Campaniloidea Douvillé, 1904 \\ Family Ampullinidae Cossmann, 1919 \\ Genus Oonia Gemmellaro, 1878}

Remarks. The genus is assigned to family Ampullinidae following Bouchet et al. (2017) and Gründel (2001), although this family is under review (Gründel \& Kaim, 2006; Kaim, pers. comm. 2018).

\section{Oonia casta Böhm, 1901}

(Figs 12.9-12.12)

1901 Oonia casta sp. nov.; Böhm, p. 221, Pl. 8, figs. 7-8.

Material. 79 specimens: MCUC.MIN (3003, 30053010, 3012-3015, 3017, 3018, 3021-3025), SGP (31722, 31723, 31736, 31742, 31745, 31746, 31750-31753, 31757, 31760-31762, 31764, 31765, 31788-31791, 31793?, 31794-31797, 31799-31803, 31825-31829, 31832, 31848-31857, 31869-31878), MUHNAC.G2.21.1.2, MUHNAC.G2.21.1.3, MUHNAC.G2.21.2, Sinemurian; OU $(40.41,68)$, upper Sinemurian, Oxynotum chronozone.

\section{Measurements.}

\begin{tabular}{l|l|l|l|l|l|l|l}
\hline Label & H & HL & HA & W & WA & $\boldsymbol{\alpha}$ & $\boldsymbol{\alpha}_{\mathbf{1}}$ \\
\hline MIN.3012 & 12.5 & 8.6 & 5.3 & 7.7 & 4.4 & - & 46.5 \\
\hline MIN.3018 & 9.5 & 6.7 & - & 5.8 & - & 72.1 & 55.4 \\
\hline
\end{tabular}

Description. The shell is preserved in some specimens. Shell moderately high turbiniform. The teleoconch has seven whorls with convex sides. Suture well-marked, almost straight. Base round and convex. Peristome is usually incomplete, but the aperture shape can be defined as oval. No ornamentation is observed. Prosocline growth lines.

Remarks. The morphological characters and dimensions are very similar to those described by Fischer et al. (2002) as Pseudomelania (Oonia) turgidula (Gemmellaro, 1878) from the lower Sinemurian of Monte Cucco (Italy). However, P. turgidula has much less convex whorls with less impressed suture, and the whorls, especially the last one, are higher than $O$. casta. Moreover, Gemmellaro (1878, p. 156) notes in the original diagnosis that the columellar lip is covered by a thin callus. This feature cannot be observed in the specimens described herein.

As both $P$. costae and $O$. casta are species with a significant number of specimens, we have considered the 
elaboration of morphometric comparisons between both species. As it was expected, both species are represented as two different groups in PCA analysis (Fig. 9), mainly explained by $\mathrm{H}$ and $\mathrm{HL}$ measurements.

\section{Order NEOGASTROPODA}

Family Purpurinidae Zittel, 1895

Remarks. Gründel (2003) assigned this family to superfamily Purpurinoidea. Nevertheless, Bouchet et al. (2017) did not recognise this superfamily.

Genus Microschiza Gemmellaro, 1878

Microschiza sp.

(Figs 12.13-12.14)

cf. 1855 Littorina clathrata Deshayes; Terquem, p. 250, P1. 14, fig. 4. cf. 1909 Litorina semiornata Münster; Brösamlen, p. 252, Pl. 19, figs. 47-48.

cf. 1988 Microschiza clathrata Deshayes; Meier \& Meiers, p. 42, 47, Pl. 8, fig. 28 a-b, Text-Fig. 7.

cf. 2003 Microschiza semiornata (Münster); Gründel, p. 28, Pl. 7, figs. 2-3.

Material. 10 specimens: MCUC.MIN.3011, SGP (31719, 31734, 31737, 31820?, 31842), Sinemurian; PO (77.1, 84), upper Sinemurian, Obtusum chronozone; PO.128.12, OU.69.6, upper Sinemurian, Oxynotum chronozone.

\section{Measurements.}

\begin{tabular}{l|l|l|l|l|l}
\hline Label & H & HL & HA & W & WA \\
\hline SGP31719 & 19.9 & 13.4 & 7.6 & 12.7 & 6.5 \\
\hline
\end{tabular}

Description. Teleoconch with five whorls. Whorls with straight flanks, slightly convex adapically. A well-marked

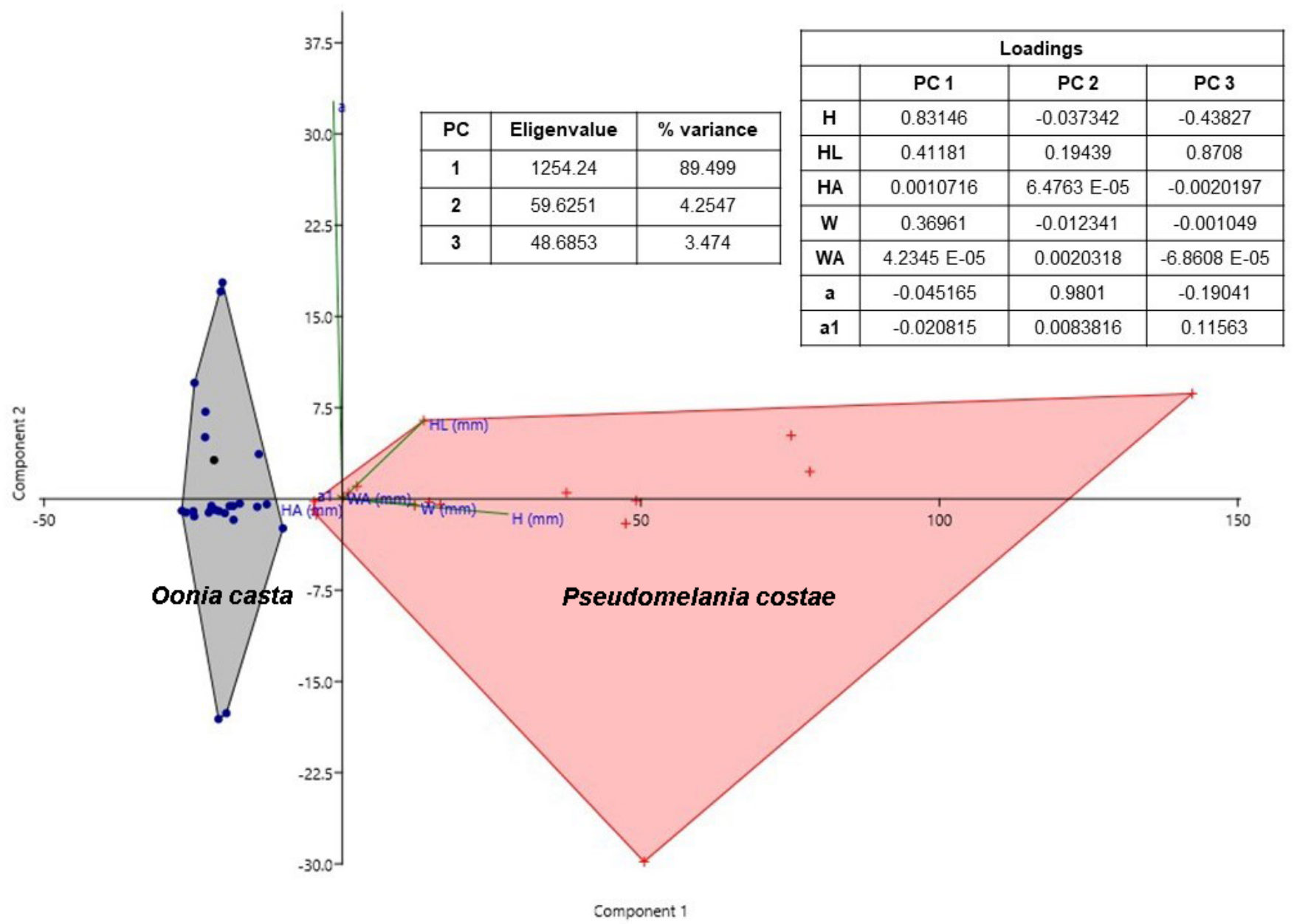

Figure 9. PCA analysis showing the morphological differentiation of the specimens, mainly explained by the H and HL measurements in the first component. Two species groups are clearly differentiated. Blue dots are the specimens assigned as Oonia casta, and red crosses are Pseudomelania costae specimens. 
sutural shelf, with a $90^{\circ}$ shoulder, gives to the shell a stairlike appearance. Aperture elliptical. The adapical margin of the whorls bears a row of tubercles. Growth lines are not preserved.

Remarks. According to Gründel (2003), Microschiza semiornata (Münster) (=Littorina clathrata Deshayes) has a high degree of intraspecific variability. The species is described from the upper Hettangian, Angulata chronozone, of S Germany and Luxembourg.

The specimen SGP31719 is labelled as coming from Praia da Polvoeira (Table 1). As Pedra do Ouro is very near, perhaps in the original labels Pedra do Ouro and Polvoeira were considered as one single location and SGP31719 might also come from the OU69 layer. The specimen SGP91842 is labelled as coming from Monte de Vera, an inland location at the south of Coimbra.

\section{Subclass HETEROBRANCHIA}

\section{Order ALLOGASTROPODA}

Remarks. Bouchet et al. (2017) do not recognise Allogastropoda. However, considering Gründel (2010), we keep this Order.

\section{Superfamily Nerinoidea Zittel, 1873}

Family Ceritellidae Wenz, 1938

Genus Boehmiola Strand, 1928

Remarks. Gründel et al. (2011) and Gründel \& Nützel (2012) maintained that Consobrinella is most probably junior synonym of Boehmiola (=Ephyra Böhm 1901, non Péron \& Lesueur, 1810). However, since the protoconch of Boehmiola is unknown, these relationships remain still uncertain.

Boehmiola exilis (Böhm, 1901)

(Fig. 10)

1901 Ephyra exilis sp. nov.; Böhm, p. 223, Pl. 8, figs. 5-6, Text-figs. 7-9.

v 1981 Boehmiola exilis; Mouterde \& Rocha, p. 56, Pl. 1, figs. 6-7.

Material. 15 specimens: SGP (31808-31817, 31863?, 31878, 31886, 31889), lower Sinemurian. OU.69.47?, upper Sinemurian, Oxynotum chronozone.

Description. Shell turriculated. The apical part of the shell and aperture are not preserved in any of the specimens. Surface of whorls slightly convex, with a narrow and pronounced sutural ramp. Collabral ribs
A

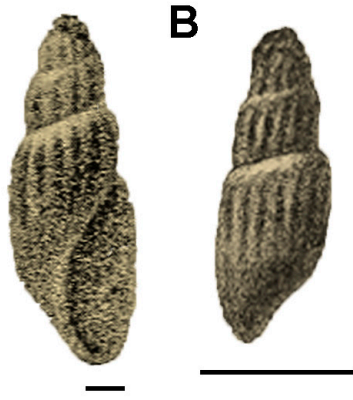

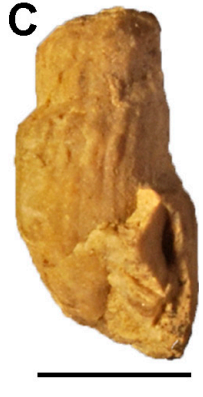

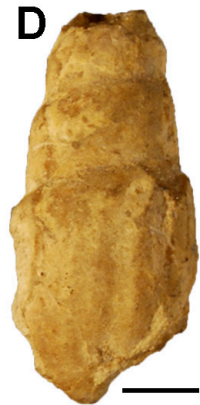

Figure 10. Boehmiola exilis. a-b) Original drawings by Böhm (1901); (a) Text-Fig. 8; (b) Pl. 8, Fig. 6. c) SGP31817. d) SGP31812. Scale bars $=5 \mathrm{~mm}$. Photo: R. Paredes.

regularly repeating, slightly opisthocline, straight to slightly prosocyrt on most of the whorl surface and becoming strongly prosocyrt in the upper part of the whorl and on the sutural shelf.

Family Nerinellidae Pchelintsev, 1960

Genus Nerinella Sharpe, 1850b

Nerinella ficalhoi Choffat, 1903

(Figs 11, 12.15-12.19)

v 1903 Nerinella ficalhoi sp. nov.; Choffat, p. 107, figs. 12-15.

v 1981 Nerinella ficalhoi; Mouterde \& Rocha, p. 59, Pl. 1, fig.13; Pl. 2, fig. 8.

Material. 42 specimens: MCUC.MIN (3002, 3036, 3037, 3039, 3040, 3050-3054, 3056-3058, 3060, 3061, 3068-3076, 3085, 3086, 3088, 3089), SGP $(1153,1154$, 1156, 31732, 31738, 31744, 31768, 31769, 31771, 31773, 31776, 31824, 31861?, 31862?), Sinemurian.

\section{Measurements.}

\begin{tabular}{l|l|l|l|l|l}
\hline Label & H & HL & HA & W & WA \\
\hline MIN.3068 & 29.1 & 6.1 & 3.7 & 6.3 & 2.5 \\
\hline SGP1154 & 29.6 & 11.4 & 6.1 & 6.3 & 2.2 \\
\hline
\end{tabular}

Description. The protoconch and first teleoconch whorls are missing in all the specimens. Shell turriculated with high spire. The most complete specimen (MCUC. MIN.3085) preserves seven whorls. Side of whorls straight with rounded shoulders and narrow sutural ramp. Suture slightly oblique. Aperture elliptical, becoming narrow adapically. Its height is more than half the height of the last whorl. Growth lines mostly prosocyrtic but closer to sigmoidal shape. The shell has a labial fold, visible in 


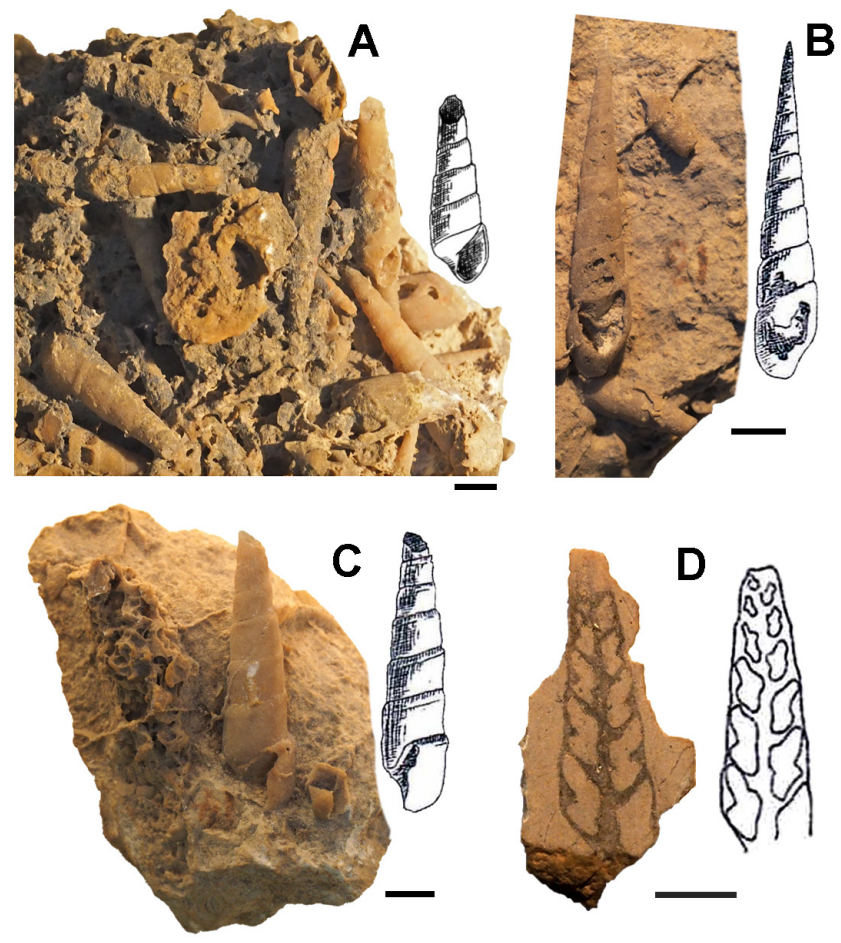

Figure 11. Original drawings by Choffat (1903) and actual photos of Nerinella ficalhoi figured specimens types. a) SGP1153(1), original of figure 12. b) SGP1153(2), original of figure 13. c) SGP1153(3), original of figure 14. d) SGP1153(4), original of figure 15. Scale bars $=5 \mathrm{~mm}$. Photos: R. Paredes.

cross-section (Fig. 11d) and in the inner moulds (Figs. 12. $15,12.16)$, and a strong columellar fold, visible in the specimen of Figure 12.17. Collabral ribs are stronger in first whorls, and tend to disappear during growth.

Remarks. Choffat (1903) and Mouterde \& Rocha (1981) indicated that this species is common in S. Pedro de Moel in the Obtusum chronozone and in the lower part of the Oxynotum chronozone.

\section{Superfamily Mathildoidea Dall, 1889}

Family Mathildidae Dall, 1889

Genus Tangarilda Gründel, 2010

Remarks. Tangarilda is a genus described as new by Gründel (2010), the type is Melania turritella Dunker, 1846 (=Cerithium subturritella d'Orbigny, 1850 nom. nov.). Gründel (2010) pointed out the presence of three spiral ribs and distinctly asymmetrical, opisthocyrt growth lines as diagnosis for this genus. Tangarilda is also described in Gründel \& Nützel (2013), where they reviewed the genera of family Mathildidae.
Tangarilda subturritella (d'Orbigny, 1850)

(Figs 12.20-12.21)

1846 Melania turritella sp. nov.; Dunker, p.169.

1847 Melania turritella; Dunker, p.109, Pl. 13, figs. 5-7.

1850 Cerithium subturritella; d'Orbigny, p.255.

1901 Promathildia turritella; Böhm, p. 216, Pl. 8, figs. 15, 17.

1981 Promathildia (Teretrina) turritella; Mouterde \& Rocha, p. 54, Pl. 1, figs. 3a-b.

1988 Promathildia turritella; Meier \& Meiers, p. 36, P1. 9, fig. 20.

2010 Tangarilda subturritella (d'Orbigny); Gründel, p. 10, Pl. 3, figs. 3-7; Pl. 4, fig. 1.

Material. 15 specimens: MCUC.MIN.3049, SGP (1155, 31733, 31786, 31864-31866, 31883-31885), MUHNAC.G2.21.2, MUHNAC.G2.21.3, Sinemurian; OU $(69.46,69.48,69.50)$, upper Sinemurian, Oxynotum chronozone.

\section{Measurements.}

\begin{tabular}{l|l|l|l|l|l|l|l}
\hline Label & H & HL & HA & W & WA & $\boldsymbol{\alpha}$ & $\boldsymbol{\alpha}_{1}$ \\
\hline OU.69.48 & 7.1 & 2.1 & - & 3.3 & - & 44.1 & 21.5 \\
\hline
\end{tabular}

Description. Shell turriculated. Whorls convex with well-marked suture. In the middle part of each whorl, there are two spiral threads of the same width. The surface of the whorl between the two spiral threads is concave. A third thread weaker than the other two can be observed adapically in the last whorl of OU.69.48. Opisthocyrtic growth lines can be observed in the specimen OU.69.48. They match with the genus diagnosis by Gründel (2010), as they are asymmetrical "with the backmost point between the adapical and the middle spiral rib".

Remarks. Gründel (2010) cited this species in lower Hettangian of Germany. Meier \& Meiers (1988) describe it as an uncommon species in the Angulata chronozone, upper Hettangian of Luxembourg. Choffat (1903) and Mouterde \& Rocha (1981) cite this species in upper Hettangian of Portugal, although this stratigraphic position should be revised.

Superfamily Cimoidea Warén, 1993

Family Cimidae Warén, 1993

Remarks. Gründel \& Nützel (2013) used the name Tofanellidae for this family. However, Bouchet et al. (2017) considered Tofanellidae as synonym of Cimidae. 


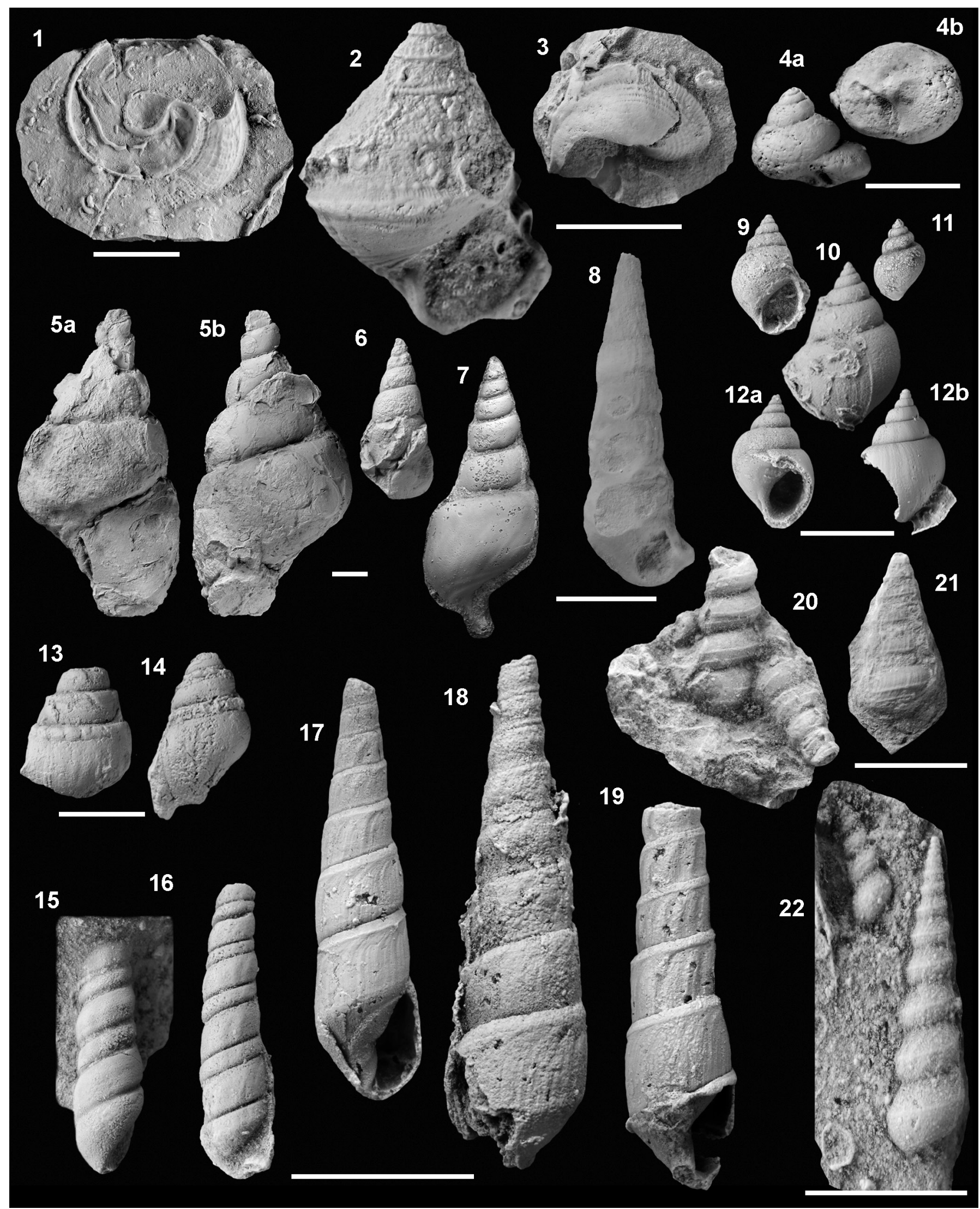


Genus Cristalloella Bandel, 1995

Cristalloella sp.

(Fig. 12.22)

Material. 4 specimens: MCUC.MIN.3062, SGP31772? Sinemurian; OU (52.20, 69.42-2), upper Sinemurian, Oxynotum chronozone.

\section{Measurements.}

\begin{tabular}{l|l|l|l|l|l|l|l}
\hline Label & H & HL & HA & W & WA & $\boldsymbol{\alpha}$ & $\boldsymbol{\alpha}_{1}$ \\
\hline MIN.3062 & 9.8 & 2.2 & - & 3.1 & - & - & - \\
\hline OU.52.20 & 8.0 & 3.9 & - & 4.3 & - & 43.2 & 25.4 \\
\hline
\end{tabular}

Description. Shell conospiral turriculated. The protoconch is not preserved. Up to twelve whorls, convex surface well-marked suture. A strong spiral keel is visible at the middle of each whorl. Growth lines are visible.

Remarks. Gründel \& Nützel (2013; p. 815) described two subgenera, Cristalloella (Cristalloella) and Cristalloella (Wonwalica). In contrast, Kaim (2004) maintained that the Cristalloella species couldn't be differentiated from the Wonwalica species at the genus level. Gründel \& Nützel (2013) indicate that Wonwalica possesses fewer whorls and is broader than the typical subgenus. In the material studied, OU.52.20 and OU.69.42 have fewer whorls, four to six, and are broader than MIN.3062 and SGP31772. Following Gründel \& Nützel (2013), OU.52.20 and OU.69.42 could belong Cristalloella (Wonwalica) sp., and MIN.3062 and SGP31772 could be Cristalloella (Cristalloella). However, due to the state of preservation and the shortage of material we cannot assure these taxonomical assignations.
Gründel \& Nützel (2013) confer to the genus a stratigraphic distribution between the Upper Triassic and the Middle Jurassic (Callovian) of Germany, France, New Zealand and North Italy.

\section{Superfamily Acteonoidea D’Orbigny, 1843}

Family Cylindrobullinidae Wenz, 1938

Remarks. Gründel \& Kaim (2006) include this family in the superfamily Acteonelloidea. Kaim (2004) includes the family Cylindrobullinidae in the superfamily Cephalaspidea. On the other hand, Gründel \& Nützel (2012) follow the assignation to superfamily Acteonoidea but include this in Order Architectibranchia. In the present paper, we follow the classification of Bouchet \& Rocroi (2005) and Bouchet et al. (2017).

Genus Cylindrobullina v. Ammon, 1878

\section{Cylindrobullina $\mathrm{sp}$.}

Material. 8 specimens: SGP $(31786,31791,31803-$ 31806, 31844), MUHNAC.G2.21.2, Sinemurian.

Description. Shell conospiral shell. Low spire with three or four whorls. Convex margins with an overlapping suture. The first whorls are very tight and the last whorl measures almost the total shell height. The aperture is long, with a rounded base that becomes narrow adapically; its height is almost equal to that of the last whorl. No ornamentation or growth lines are visible.

Remarks. It has been no possible to figure this species because of the preservation state and because as all the

Figure 12. 1) Cyclostomaria aff. monarii Oxynotum chronozone, Praia Pedra do Ouro beach, Água de Madeiros Fm. Cross section, with part of the shell preserved. OU.68.11. 2-3) Eucycloscala sp. Oxynotum chronozone, Praia da Pedra do Ouro beach, Água de Madeiros Fm. Apertural views showing detail of the selenizone and the spiral rib with nodules; (2) OU.47.12; (3) OU.40.7. 4) Ataphridae indet. Oxynotum chronozone, Praia Pedra do Ouro beach, Água de Madeiros Fm. Lateral and basal views. OU.69.10. 5-7) Pseudomelania costae, (5) Oxynotum chronozone, Praia da Polvoeira, Água de Madeiros Fm.; apertural (5a) and dorsal (5b) views. PO.54.2; (6 -7) Obtusum chronozone, S. Pedro de Moel, Coimbra Fm.; (6) apertural view, MCUC.MIN.3078; (7) dorsal view, MCUC.MIN.2999. 8) Pseudokatosira? aff. undulata, Oxynotum chronozone, Praia da Pedra do Ouro beach, Água de Madeiros Fm. Lateral view. OU.40.1. 9-12) Oonia casta, Obtusum chronozone, Praia da Concha, Coimbra Fm.; (9) apertural view. MCUC.MIN.3012; (10) dorsal view showing the pattern of growth lines. MCUC.MIN.3009; (11) apertural view. MCUC.MIN.3018; apertural (12a) and dorsal (12b) views showing the pattern of growth lines. MCUC.MIN.3013. 13-14) Microschiza sp., Oxynotum chronozone, Praia da Polvoeira, Água de Madeiros Fm. Dorsal views showing a row of tubercles. 15-19) Nerinella ficalhoi, Obtusum chronozone, Coimbra Fm.; $(\mathbf{1 5}, \mathbf{1 6})$ Penedo da Saudade (S. Pedro de Moel). Inner moulds, lateral and apertural views; (15) MCUC.MIN.3037; (16) MCUC.MIN.3052; (17-19) Penedo do Cabo, apertural and dorsal views showing detail of the whorl surface; (17) MCUC. MIN.3085; (18) MCUC.MIN.3086; (19) MCUC.MIN.3088. 20-21) Tangarilda subturritella. Dorsal views; (20) Obtusum chronozone, Penedo da Saudade (SPM), Coimbra Fm., MCUC.MIN.3049; (21) Oxynotum chronozone, Praia da Pedra do Ouro beach, Água de Madeiros Fm., OU.69.48. 22) Cristalloella sp., Obtusum chronozone, Penedo da Saudade (SPM), Coimbra Fm. Dorsal views showing detail of the whorl surface. MCUC.MIN.3062. Scale bars in Figures (1-3, 5-7, 9-19) $=10 \mathrm{~mm}$; Scale bars in Figures $(4,8,20-22)=5 \mathrm{~mm}$. 
specimens are embedded in rock, it was no possible to take high-quality photos. Nevertheless regarding the preserved features these specimens match with those describe and figure by Böhm (1901; p. 266, pl. 8, fig. 19), and it has been considered interesting to leave proof of the presence of this taxa.

\section{DISCUSSION AND CONCLUSIONS}

A total of 386 Sinemurian gastropod specimens were studied. Of these, 96 were newly collected in the S. Pedro de Moel area and 290 were from museum collections. Among the new collected material, 77 specimens came from Pedro do Ouro (OU) and 19 from Polvoeira (PO) sections. From the main museum collections (the Museu Geológico de Portugal and Museu da Ciência - University of Coimbra), 283 Sinemurian gastropods were studied: 198 from SGP and 85 from MCUC. Moreover, other 5 specimens from MUHNAC and 2 from UP.MHNFCP are catalogued as Sinemurian.

Among these 386 specimens, 266 have been taxonomically identified (Table 1; Supplementary Information); the other 120 specimens were simply recognized as Gastropoda. 147 specimens from SGP, 62 from MCUC, and all the specimens from MUHNAC and UP.MHNFCP have been identified (Table 1). Moreover, 44 from $\mathrm{OU}$ and 6 from $\mathrm{PO}$ have been determined at some taxonomical level.

Adding to these 386 specimens, 5 bed samples from SPM (Figs 2, 3a) and PV (Figs 2, 3b-3d), that include numerous gastropod specimens, were studied. These specimens were not removed from the sediment in order to study in detail the distribution of the gastropod shells and their state of preservation. All of them were regarded taphonomically as autochthonous assemblages (FernándezLópez, 2000), giving valuable information about the type of preservation and palaeocommunities approaches.

The following taxa have been identified in these samples: a) $S P M$ (Fig. 3a). This is a monospecific sample of Nerinella ficalhoi; b) PV322b_l (Fig. 3b). 56 specimens have been counted: 50 of them represent Tangarilda subturritella, with heights between 4.7 and $12.3 \mathrm{~mm}, 2$ specimens belong to Pseudomelania indet., and 2 specimens to Cylindrobullina sp; c) PV322b_2 (Fig. 3c). 17 specimens have been counted: 13 represent T. subturritella, with height between 8.1 and $10.3 \mathrm{~mm}, 3$ specimens belong to Oonia casta, one is fragmented and the others show heights of 15.4 and $18.6 \mathrm{~mm}$, and one specimen represents Pseudomelania costae, which has a height of $24.6 \mathrm{~mm}$; d) PV322mt (Fig. 3d). From PV322 there are two sample assemblages in which $P$. costae and T. subturritella dominate. In the first one, 11 specimens have been counted: 7 of $P$. costae and 4 of $T$. subturritella. One specimen of $P$. costae preserves three whorls, with a total height of $52.1 \mathrm{~mm}$, another almost complete one has a height of $42.8 \mathrm{~mm}$. There are other smaller ones, and the lowest height is $17.7 \mathrm{~mm}$. The T. subturritella specimens present homogeneous heights of $5.7 \mathrm{~mm}$. The second sample has 18 specimens, 14 of $T$. subturritella, with heights between 3.3 and $8.6 \mathrm{~mm}$. The other 4 specimens belong to $P$. costae; two are incomplete, the larger one preserves three whorls with a height of $18.6 \mathrm{~mm}$, the third one is almost complete, with a height of $15.2 \mathrm{~mm}$ and the fourth is the smallest, with a height of $3.8 \mathrm{~mm}$. Other 3 specimens can be observed in axial cross-section.

In summary, in the layer 322, the most frequent species are T. subturritella and P. costae. Moreover, O. casta and Cylindrobullina sp. can be found albeit less frequently. To date, Nerinella ficalhoi has only been found in the stratigraphically lowest level, that one cited by Choffat as bed 4 ("Cam.4") of Penedo do Cabo. It is located most probably below the bed 315 of Azerêdo et al. (2010; fig. 3) $\log$. Future research should specify the precise position of these records. The most continuous and best-exposed upper Sinemurian p.p. outcrops are located in the vicinity of S. Pedro de Moel, including OU and PO sections, where 300 of the 386 specimens $(77.72 \%)$ come from. The outcrops of Coimbra Fm. located inland are badly exposed or inaccessible, but 59 specimens (15.28\%) could be studied in the SGP collection, the only one that keep gastropods from these outcrops.

The specimens of $P$. costae and $O$. casta, labelled as coming from Penedo do Cabo, Penedo da Saudade and S. Pedro de Moel, likely belong to levels close to those of the Obtusum chronozone sampled at the Praia Velha and Praia $\mathrm{da}$ Concha. The specimens labelled in SGP as coming from Polvoeira belong to species also identified in Praia Pedra do Ouro (OU) and Praia da Polvoeira (PO) sections, which most probably indicates that they precisely come from the same outcrops studied recently in this area. In relation with the stratigraphic distribution of the taxa studied, it is remarkable that Pseudomelania costae and Oonia casta are the most frequent and widely distributed species, being found in the Obtusum and Oxynotum chronozones.

Nerinella ficalhoi and Cylindrobullina sp. have been only found in the Obtusum chronozone. Microschiza sp., Pseudokatosira? aff. undulata, Eucycloscala sp., and Cyclostomaria aff. monarii have only been recorded in the Oxynotum chronozone.

Tangarilda subturritella, which is common in the Obtusum chronozone, has also been identified in the bed OU69 of the Oxynotum chronozone.

Cryptaenia sp., Boehmiola exilis, and Scurriopsis (Scurriopsis) schmidti have only been identified in the SGP collection; they were labelled as coming from the Almaroz site. This is the only locality where this association has been recognised. 
Microschiza sp., T. subturritella, and S. (S.) schmidti have been cited in the upper Hettangian of Luxembourg and SW Germany. Different species of Nerinella have been identified in $\mathrm{N}$ Europe, in older stratigraphic levels than those of S Europe (Sharpe, 1850b). These data open up an interesting path of research into possible north-southern migration way. In agreement with this hypothesis, similar forms to ones described here as Pseudokatosira? aff. undulata and Eucycloscala sp. have been found in lower Sinemurian levels of German and Austrian outcrops. In contrast, forms similar to Cyclostomaria aff. monarii and B. exilis have been described in the Pliensbachian of the Bakony Mountains (Hungary) and of Dorset (England), respectively.

To date, $N$. ficalhoi has only been cited in LB; thus, it might constitute an endemic species. This could also be the case of $P$. costae and $O$. casta.

\section{ACKNOWLEDGEMENTS}

Acknowledgments are due to Dr Roberto Gatto for the detailed revision of the manuscript; to both reviewers, Dr Stefano Monari and Dr Mariel Ferrari, for providing valuable comments on the manuscript; to Dr Luís Vítor Duarte (Marine and Environment Research Centre, Faculdade de Ciências e Tecnología, Universidade de Coimbra) for the cession of Figure 2; to Dr Miguel Ramalho and his collaborators (Museu Geológico de Portugal), João Muchagata (MHNC-UP), Susana Machado (LNEG-Alfragide), Liliana Póvoas and João Paulo Lopes (MUHNAC) for their attention in their institutions, to Museu da Ciência (University of Coimbra) management, for lending the Sinemurian gastropod collection; to Cormac De Brun for the English review of the manuscript. We emphasise with special thanks the photographic work and collaboration edition of images received from Carlos Alonso (UCM). This paper benefited from the use of the Portuguese Infrastructure of Scientific Collections (PRISC.pt). This work is a contribution to the Portuguese E-Infrastructure for Information and Research on Biodiversity (PORBIOTA) and to the project CGL2015-66604-R (MINECO, Spain) and to the UCM group 910431 "Procesos Bióticos Mesozoicos".

\section{REFERENCES}

Ammon, L. von 1878. Die Gastropoden des Hauptdolomites und des Plattenkalkes der Alpen. Abhandlungen des zoologisch mineralogischen Vereins zu Regensburg, 11, $1-72$.

Azerêdo, A.C., Silva, R.L., Duarte, L.V. \& Cabral, M.C. 2010. Subtidal stromatolites from the Sinemurian of the
Lusitanian Basin (Portugal). Facies, 56, 211-230; doi: 10.1007/s10347-009-0198-0.

Azerêdo, A.C., Duarte, L.V. \& Silva, R.L. 2014. Configuração sequencial em ciclos ( $2^{\mathrm{a}}$ ordem) de fácies transgressivasregressivas do Jurássico Inferior e Médio da Bacia Lusitânica (Portugal). Comunicações Geológicas, 101, 383-386.

Bandel, K. 1995. Mathildoidea (Gastropoda, Heterostropha) from the Late Triassic St. Cassian Formation. Scripta Geologica, 111, 1-83.

Bandel, K. 2009. The slit bearing nacreous Archaeogastropoda of the Triassic tropical reefs in the St. Cassian Formation with evaluation of the taxonomic value of the selenizone. Berliner paläobiologische Abhandlungen, 10, 5-47.

Böhm, J. 1901. Ueber die fauna der Pereiros-Schichten. Zeitschrift der Deutschen Geologischen Gesellschaft, 211-252.

Bouchet, P. \& Rocroi, J-P. 2005. Classification and nomenclator of gastropod families. Malacologia, 47, 1-397.

Bouchet, R., Rocroi, J-P., Hausdorf, B., Kaim, A., Kano, Y., Nützel, A., Parkhaev, P., Schrödl, M. \& Strong, E.E. 2017. Revised classification, nomenclator and typification of gastropod and monoplacophoran families. Malacologia, 61, 1-526.

Brösamlen, R. 1909. Beitrag zur Kenntnis der Gastropoden des schwäbischen Jura. Palaeontographica, 56, 177-321.

Choffat, P. 1903. L'Infralias et le Sinémurien du Portugal. Comunicações da Comissão do Serviço Geológico de Portugal, 5, 49-114.

Comas-Rengifo, M.J., Duarte, L.V., Goy, A., Paredes, R. \& Silva, R.L. 2013. El Sinemuriense Superior (cronozonas Oxynotum y Raricostatum) en la región de S. Pedro de Moel (Cuenca Lusitánica, Portugal). Comunicações Geológicas, 100, 15-19.

Conti, M.A., Monari, S. \& Szabó, J. 2004. An overview of the Jurassic gastropods from Rocca Busambra (northwestern Sicily, Italy). Rivista Italiana di Paleontologia e Stratigrafia, 110, 43-51.

Cossmann, M. 1895. Essais de Paléoconchologie Comparée 1. Published by the author and Comptoire Geologique, Paris.

Cossmann, M. 1915. Etude complémentaire sur le Charmouthien de la Vendée. Bulletin de la Société Géologique de Normandie, 33, 113-159.

Cossmann, M. 1919. Monographie illustrée des mollusques oligocèniques des environs de Rennes. Journal de Conchyliologie, 64, 133-199.

Cox, L.R. 1960. Gastropoda. General characteristics of Gastropoda. In: Treatise on Invertebrate Paleontology (ed. Moore, R.C.). Geological Society of America, Inc. \& University of Kansas Press, New York, 85-168.

Cuvier, G. 1795. Secon mémoire sur l'organisation et les rapports des animaux à sang blanc, dans lequel on traite de la structure des Mollusques et de leur division en ordres, lu à la Société d'historia naturelle de Paris, le 11 Prairial, an III. Magazin Encyclopédique, ou Journal des Sciencies, des Lettres et des Arts, 2, 433-449. 
Dall, W.H. 1889. Reports on the results of the dredging, under the supervision of Alexander Agassiz in the Gulf of Mexico (1877-1878) and in the Caribbean Sea (1879-1880), by the U. S. Coast survey steamer "Blake", during 1891, lieut.-commander C.D. Sigsby U.S.N., and commander J.R. Barlett, U.S.N., commanding. XXIX Report on the Mollusca. Part II. Gastropoda and Cephalopoda. Bulletin of the Museum of Comparative Zoology, 18, 1-423.

Damborenea, S.E. \& Ferrari, S.M. 2008. El género Lithotrochus Conrad (Gastropoda, Vetigastropoda) en el Jurásico temprano de Argentina. Ameghiniana, 45, 197-209.

Deslongchamps, M.E. 1863-1869. Notes Paléontologiques. Volume 1. Savy, Paris.

Dommergues, J-L., Meister, C. \& Rocha, R.B. 2010. The Sinemurian ammonites of the Lusitanian Basin (Portugal): an example of complex endemic evolution. Palaeodiversity, 3, 59-87.

d'Orbigny, A. 1842-1843. Paléontologie Française. Description Zoologique et Géologique de tous les Animaux Mollusques et Rayonnés Fossils de France. Terrains Crétacés. Tome Second. Arthus Bertrand, Paris.

d'Orbigny, A. 1850-1852. Prodrome de Paléontologie Stratigraphique Universelle des Animaux Mollusques et Rayonnes. Victor Masson, Paris.

Douvillé, H. 1904. Mollusques fossiles. In: Mission Scientifique en Perse. Tome 3, Part 4 (ed. Morgan, J. de). Ernest Leroux, Paris.

Duarte, L.V., Silva, R.L., Duarte, C.B., Azerêdo, A.C. \& Comas-Rengifo, M.J. 2008. Litostratigrafia do Jurássico Inferior da região de S. Pedro de Moel (Bacia Lusitânica, Portugal). In: A Terra, Conflitos e Ordem. Homenagem ao Professor Ferreira Soares (eds Callapez, P.M., Rocha, R.B., Marques, J.F., Cunha, L.S. \& Dinis, P.M.). Museu Mineralógico e Geológico da Universidade de Coimbra, Coimbra, 175-185.

Duarte, L.V., Silva, R.L., Oliveira, L.C.V., Comas-Rengifo, M.J. \& Silva, F. 2010. Organic-rich facies in the Sinemurian and Pliensbachian of the Lusitanian Basin, Portugal: Total Organic Carbon distribution and relation to transgressiveregressive facies cycles. Geologica Acta, 8, 325-340; doi: 10.1344/105.000001536.

Duarte, L.V., Silva, R.L., Mendonça Filho, J.G., Ribeiro, N.P. \& Chagas, R.B.A. 2012. High-resolution stratigraphy, palynofacies and source rock potential of the Agua de Madeiros formation (lower Jurassic), Lusitanian basin, Portugal. Journal of Petroleum Geology, 35, 105-126; doi: 10.1111/j.1747-5457.2012.00522.x.

Dunker, W. 1844. Vorläufige diagnosen mehrerer neuer conchylien aus der norddeutschen Liasbildung, die nächstens ausfürlicher beschrieben und abgebildet erscheinenwerden. Zeitschrift für Malakozoologie, 1, 186-188.

Dunker, W. 1846. Diagnosen einiger neuer Konchylien aus der norddeutschen Liasbildung. Zeitschrift für Malakozoologie, 3, 168-170.

Dunker, W. 1847. Ueber die in dem Lias bei Halberstadt vorkommenden Versteinerungen. Palaeontographica, 1, $34-41$.
Fernández-López, S.R. 2000. Temas de Tafonomía. Departamento de Paleontología, Universidad Complutense de Madrid, Madrid.

Ferrari, S.M. 2009. Cosmopolitan Early Jurassic marine gastropods from west-central Patagonia, Argentina. Acta Palaeontologica Polonica, 54, 449-461; doi: 10.4202/ app.2008.0070.

Ferrari, S.M. 2013. New Early Jurassic gastropods from west-central Patagonia, Argentina. Acta Palaeontologica Polonica, 58, 579-593; doi: 10.4202/app.2011.0090.

Ferrari, S.M. 2014. Early Jurassic marine gastropods from Argentina: a palaeobiogeographical análisis based on Vetigastropoda. Journal of Systematic Palaeontology, 13, 1-23; doi: 10.1080/14772019.2014.967319.

Ferrari, M. \& Kaim, A. 2019. Onshore-offshore trend in the evolution of calliotropid gastropods expressed in shell morphology. Journal of Systematic Palaeontology, 17, 269-286; doi: 10.1080/14772019.2017.1407371.

Ferrari, S.M., Kaim, A. \& Damborenea, S.E. 2014. The genera Calliotropis Seguenza and Ambercyclus n. gen. (Vetigastropoda, Eucyclidae) from the early Jurassic of Argentina. Journal of Paleontology, 88, 1174-1188; doi: 10.1666/13/147.

Fischer, J.C., Rosati, F. \& Raffi, S. 2002. Gastropodes sinémuriens du Monte Cucco (Apennins d'OmbrieMarche, Italie centrale). Geobios, 35, 441-456; doi: 10/1016/S0016-6995(02)00039-6.

Forbes, E. 1850. On the genera of British Patellacea. Report of the $19^{\text {th }}$ meeting of the British Association for the Advancement of Science (Birmingham, 1849). Notices and Abstracts of Communication, 75-76.

Gabb, W.M. 1869. Cretaceous and Tertiary fossils. California Geological Survey, Paleontology, 2, 1-299.

Gatto, R. \& Monari, S. 2010. Pliensbachian gastropods from Venetian Southern Alps (Italy) and their palaeobiogeographical significance. Palaeontology, 53, 771-802; doi: 10.1111/j.1475-4983.2010.00961.x.

Gatto, R., Monari, S., Neige, P., Pinard, J.D. \& Weis, R. 2015. Gastropods from upper Pliensbachian-Toarcian (Lower Jurassic) sediments of Causses Basin, southern France and their recovery after the early Toarcian anoxic event. Geological Magazine, 152, 871-901; doi: 10.1017/ S0016756814000788.

Gemmellaro, G.G. 1878. Sui fossili del calcare cristallino delle Montagne del Casale e di Bellampo nella provincia di Palermo. Giornale di Scienze Naturali ed Economiche, 13, 116-212.

Gemmellaro, G.G. 1879. Sui fossili del calcare cristallino delle Montagne del Casale e di Bellampo nella provincia di Palermo. Giornale di Scienze Naturali ed Economiche, 14, 157-212.

Gray, J.E. 1840. Shells of molluscous animals. Synopsis of the contents of the British Museum, 42, 105-152.

Gründel, J. 2001. Neritomorpha und Caenogastropoda (Gastropoda) aus dem Dogger Norddeutschlands und des nordwestlichen Polens. Berliner geowissenschaftliche Abhandlungen, E36, 45-99. 
Gründel, J. 2003. Gastropoden aus dem Unteren Lias (OberHettangium bis Unter-Sinemurium) Südwestdeutschlands. Stuttgarter Beiträge zur Naturkunde. Serie B, 340, 1-55.

Gründel, J. 2007a. Jurassische Gastropoden aus der Betakalkbank (oberes Sinemurium, obere ObtusumZone) Südwestdeutschlands. Stuttgarter Beiträge zur Naturkunde. Serie B, 370, 1-29.

Gründel, J. 2007b. Gastropoden des Pliensbachiums (unterer Jura) aus der Usedom-Senke (Nordostdeutschland). Zitteliana. Serie A, 47, 69-103.

Gründel, J. 2008. Remarks to the classification and phylogeny of the Ataphridae Cossmann, 1915 (Gastropoda, Archaeogastropoda) in the Jurassic. Neues Jahrbuch für Geologie und Paläontologie, Abhandlungen, 250, 177-197.

Gründel, J. 2010. Neubeschreibung der Gastropodenfauna aus dem Hettangium (unterster Jura) des Kanonenberges bei Halberstadt (Deutschland). Beringeria, 41, 3-24.

Gründel, J. 2011. Die Ptychomphalidae Wenz, 1938, (Ptychomphaloidea, Gastropoda) im Jura. Paläontologie, Stratigraphie, Fazies (19): Freiberger Forschungshefte, C 539, 59-69.

Gründel, J. \& Kaim, A. 2006. Shallow-water gastropods from Late Oxfordian sands in Kłęby (Pomerania, Poland). Acta Geologica Polonica, 56, 121-157.

Gründel, J. \& Nützel, A. 2012. On the early evolution (Late Triassic to Late Jurassic) of the Architectibranchia (Gastropoda: Heterobranchia), with a provisional classification. Neues Jahrbuch für Geologie und Paläontologie, Abhandlungen, 264, 31-59.

Gründel, J. \& Nützel, A. 2013. Evolution and classification of Mesozoic mathildoid gastropods. Acta Palaeontologica Polonica, 58, 803-826; doi: 10.4202/app.2012.0052.

Gründel, J., Kaim, A., Nützel, A. \& Little, C.T. 2011. Early Jurassic gastropods from England. Palaeontology, 54, 481-510; doi: 10.1111/j.1475-4983.2011.01043.x.

Hallam, A. 1971. Facies analysis of the Lias in West Central Portugal. Neues Jahrbuch für Geologie und Paläontologie Abhandlungen, 139, 226-265.

Hoernes, R. 1884. Elemente der Palaeontologie (Palaeozoologie). Von Veit \& Co., Leipzig.

Kaim, A. 2004. The evolution of conch ontogeny in Mesozoic open sea gastropods. Palaeontologia Polonica, 62, 3-183.

Kaim, A., Jenkins, R.G., Tanabe, K. \& Kiel, S. 2014. Mollusks from late Mesozoic seep deposits, chiefly in California. Zootaxa, 3861, 401-440; doi: 10.11646/zootaxa.3861.5.1.

Kano, Y. 2008. Vetigastropod phylogeny and a new concept of Seguenzioidea: independent evolution of copulatory organs in the deep-sea habitats. Zoologica Scripta, 37, 1-21; doi: 10.1111/j.1463-6409.2007.00316.x.

Knight, J.B. 1930. The gastropods of the Saint Louis, Missouri, Pennsylvanian outlier: the Pseudozygopleurinae. Journal of Paleontology, 4 (Suppl. 1), 1-88.

Koken, E. 1896. Die Gastropoden der Trias um Hallstadt. Jahrbuch der Kaiserlich-Königlichen Geologischen Reichsanstalt, 46, 37-126.

Meier, H. \& Meiers, K. 1988. Die Gastropodenfauna der "Angulata-zone" des Steinbruchs "Reckingerwald" bei Brouch. Travaux Scientifiques du Musée National d'Histoire Naturelle de Luxembourg, 13, 1-87.

Monari, S., Valentini, M. \& Conti, M.A. 2011. Earliest Jurassic patellogastropod, vetigastropod, and neritimorph gastropods from Luxembourg with considerations on the Triassic-Jurassic faunal turnover. Acta Palaeontologica Polonica, 56, 349-384; doi: 10.4202/app.2010.0098.

Monari, S., Gatto, R. \& Valentini, M. 2018. Vetigastropoda and Neritimorpha from the Lower Bajocian of Luxembourg and palaeobiogeography of AalenianBajocian (Middle Jurassic) gastropods of western Europe. Journal of Systematic Palaeontology, 16, 449-492; doi: 10.1080/14772019.2017.1312578.

Mouterde, R. \& Rocha, R.B. 1981. Atlas des fossiles caractéristiques du lias portugais. I-Lias inférieur. Ciências da Terra (UNL), 6, 49-76.

Nützel, A. \& Gründel, J. 2007. Two new gastropod genera from the Early Jurassic (Pliensbachian) of Franconia (South Germany). Zitteliana, 47, 59-67.

Nützel, A. \& Gründel, J. 2015. Early Jurassic (Pliensbachian) gastropods from Franconia, Southern Germany. Palaeontographica Abteilung A, 305, 1-87.

Okan, Y. \& Hosgör, I. 2007. The Bivalvia and Gastropoda fauna of the Ammonitico Rosso Facies of Late SinemurianEarly Pliensbachian of the Kösrelík region (NE AnkaraTurkey): First record of annelid polychaete species and their paleogeographic and paleoecologic characteristics. Bulletin of the Mineral Research and Exploration, 135, 19-29.

Paredes, R. 2012. Bivalves do Sinemuriano da Bacia Lusitânica. Registros paleontológicos com importância para a valorização do patrimonio geológico português. MSc. Thesis, University of Coimbra.

Paredes, R., Comas-Rengifo, M.J. \& Duarte, L.V. 2013. Moluscos bivalves da Formação de Água de Madeiros (Sinemuriano superior) da Bacia Lusitânica (Portugal). Comunicações Geológicas, 100, 21-27.

Paredes, R., Comas-Rengifo, M.J., Duarte, L.V., García Joral, F. \& Goy, A. 2016. The earliest Jurassic brachiopod record in the Lusitanian Basin: Palaeoecological insights. Cuadernos del Museo Geominero, 20, 465-470.

Pchelintsev, V.F. 1960. Superfamily Murchisoniacea. In: Osnovy Paleontologii, Molliuski, Briukhonogie (eds Pchelintsev, V.F. \& Korobkov, I.A.). Nauka, Moscow. 1-360.

Péron, F. \& Lesueur, C.A. 1810. Tableau des caractères génériques et spécifiques de toutes les espèces de méduses connues jusqu'à ce jour. Annales du Muséum National d'Histoire Naturelle de Paris, 14, 325-366.

Pictet, F.J \& Campiche, G. 1862. Description des Fossiles du Terrain Crétacé des Environs de Saint-Croix. Dieuxieme Partie. J. Kessmann \& H. Georg, Geneva.

Rafinesque, C.S. 1815. Analyse de la Nature ou Tableau de l'Univers et des Corps Organisés. Jean Barravecchia, Palerme.

Schubert, S., Gründel, J. \& Nützel, A., 2008. Early Jurassic (Upper Pliensbachian) gastropods from the Herforder Liasmulde (Bielefeld, Northwest Germany). Paläontologische Zeitschrift, 82, 17-30. 
Sharpe, D. 1850a. On the secondary district of Portugal which lies on the North of the Tagus. Quarterly Journal of the Geological Society, 6, 135-201.

Sharpe, D. 1850b. Remarks on the genus Nerinea, with an account of the species found in Portugal. Quarterly Journal of the Geological Society, 6, 101-115.

Stoliczka, F. 1861. Über die Gastropoden und Acephalen der Hierlatz-Schichten. Sitzungsberichte der MatematischNaturwissenschaftliche Klasse der kaiserlich-königlichen Akademie der Wissenschaften, 43, 157-204.

Strand, E. 1928. Miscellanea nomenclatorica zoologica et palaeontologica, I-II. Archiv für Naturgeschichte, 92A, 30-75.

Szabó, J. 1980. Lower and Middle Jurassic Gastropods from the Bakony Mountains (Hungary). Part II. Pleurotomariacea and Fissurellacea (Archaeogastropoda). Annales historiconaturales Musei nationalis hungarici, 72, 49-71.

Szabó, J. 2008a. Gastropods of the Early Jurassic Hierlatz Limestone Formation; part 1: a revision of type collections from Austrian and Hungarian localities. Fragmenta Palaeontologica Hungarica, 26, 1-108.

Szabó, J. 2008b. A nomenclatorial revision of Pleurotomaria suessii Hörnes, 1853 and Cyclostomaria Szabó, 1980 (Pleurotomarioidea, Gastropoda). Neues Jahrbuch für Geologie und Paläontologie Abhandlungen, 250, 167-176; doi: 10.1127/0077-7749/2008/0250-0167.

Szabó, J. 2016. Gastropods of the Lower Jurassic Hierlatz Limestone Formation, part 2.: some new archaic type slit-bearing components from the fauna of the Hierlatz Alpe (Hallstatt, Austria) and the Bakony Mts (Hungary). Fragmenta Palaeontologica Hungarica, 33, 3-30; doi: 10.17111/FragmPalHung.2016.33.3.
Szabó, J., Conti, M.A., Monari, S. \& Wendt, J. 2019. Gastropods from the Jurassic Neptunian sills of Rocca Busambra (North-Western Sicily, Italy): Patellogastropoda, Pleurotomarioidea, Scissurelloidea, Fissurelloidea and Eucycloidea. Papers in Palaeontology, 1-84; doi: 10.1002/ spp2.1258 (published online 31 August 2019).

Terquem, O. 1855. Paleontologie de l' etage inferieur de la formation liasique de la province de Luxembourg, GrandDuche (Hollande) et de Hettange (du Département de la Moselle). Mémoires de la Société géologique de France, 5, 219-343.

Todd, J. \& Munt, M. 2010. Mollusca - Gastropods. In: Fossils from the Lower Lias of the Dorset Coast (eds Lord, A.R. \& Davis P.G.). The Palaeontological Association, Londres, 147-168.

Verril, A.E. 1884. Second catalogue of Mollusca recently added to the fauna of the New England coast and the adjacent part of the Atlantic, consisting mostly of deepsea species, with notes on others previously recorded. Transactions of the Connecticut Academy of Arts and Sciences, 6, 139-194.

Warén, A. 1993. New and little known Mollusca from Iceland and Scandinavia. Part 2. Sarsia, 78, 159-201.

Wenz, W. 1938-1944. Gastropoda. Prosobranchia. In: Handbuch der Paläozoologie, Band 6 (ed. Schindewolf, O.H.). Verlag von Gebrüder Borntraeger, Berlin, 1-1639.

Zieten, K.H. von 1830-1832. Die Versteinerungen Würtembergs. Stuttgart.

Zittel, K.A. 1873. Die Gastropoden der Stramberger Schichten. Palaeontographica, 2, 1-373.

Zittel, K.A. 1895. Grundzüge der Paläontologie. R. Oldenbourg, Munich. 